\title{
Chemistry and Sr-Nd isotope signature of amphiboles of the magnesio-hastingsite-pargasite-kaersutite series in Cenozoic volcanic rocks: Insight into lithospheric mantle beneath the Bohemian Massif
}

\author{
Jaromír Ulrych a , Lukáš Krmíček a,b,*, Claudia Teschner ${ }^{c}$, Roman Skála a , Jiří Adamovič a , Jana Ďurišová a , \\ Šárka Kř̌ižová ${ }^{a}$, Simona Kuboušková ${ }^{\mathrm{d}}$, Miroslav Radoň ${ }^{\mathrm{e}}$ \\ a Institute of Geology of the Czech Academy of Sciences, Rozvojová 269, 16502 Praha 6, Czech Republic \\ b Brno University of Technology, Faculty of Civil Engineering, AdMaS Centre, Veveři 95, 60200 Brno, Czech Republic \\ c Department für Geo- und Umweltwissenschaften, Ludwig-Maximilians-Universität München, Theresienstraße 41, D-80333 München, Germany \\ d Department of Geological Sciences, Faculty of Science, Masaryk University, Kotlářská 2, 61137 Brno, Czech Republic \\ e Regional Museum Teplice, Zámecké náměstí 14, 41501 Teplice, Czech Republic
}

\section{A R T I C L E I N F O}

\section{Article history:}

Received 4 February 2018

Accepted 14 May 2018

Available online 17 May 2018

\section{Keywords:}

Bohemian Massif

Cenozoic volcanic rocks

Ti-amphibole

Sr-Nd isotopes

Mantle metasomatism

\begin{abstract}
A B S T R A C T
Amphibole phenocrysts, xenocrysts and cumulate xenoliths from Cenozoic volcanic rocks of the Bohemian Massif (BM) belong to the magnesio-hastingsite-pargasite-kaersutite series. Their host rocks are mostly basaltic lavas, stocks, dykes and breccia pipe fills, less commonly also felsic rocks. Felsic rocks with amphibole cumulate xenoliths represent differentiated magmas which have undergone polybaric fractionation of the mafic minerals. The calculated $\mathrm{p}-\mathrm{T}$ conditions suggest that almost all amphiboles crystallized in a relatively narrow temperature range (1020-1100 ${ }^{\circ} \mathrm{C}$ ) at depths of $\sim 20-45 \mathrm{~km}(0.7-1.2 \mathrm{GPa}$ ) during the magma ascent. These p-T estimates are compatible with the published experimental data on the stability of kaersutite. We therefore suggest the presence of a deep magma chamber situated close to the crust-mantle boundary where amphibole xenoliths to megacrysts could have formed. Nevertheless, crystallization of rare amphibole rims during the magma ascent was observed in a hornblendite cumulate in sodalite syenite from "Giegelberg". The lowest concentration of incompatible elements in the amphiboles was found in xenocrysts in alkaline basaltic rocks and mantle xenoliths and megacrysts, followed by phenocrysts/xenocrysts in lamprophyric rocks, xenocrysts of cumulates in felsic rocks, and phenocrysts in subvolcanic rocks. Amphibole compositional and Sr-Nd isotope characteristics resemble those of amphiboles from metasomatic clinopyroxene/amphibole veins in mantle peridotites. The initial ${ }^{143} \mathrm{Nd} /{ }^{144} \mathrm{Nd}$ and ${ }^{87} \mathrm{Sr} /{ }^{86} \mathrm{Sr}$ ratios of amphiboles $(0.51266-0.51281$ and $0.70328-0.70407$, respectively) are similar to those of their whole rocks (0.51266-0.51288 and 0.70341-0.70462, respectively). Amphiboles of the magnesio-hastingsite-pargasite-kaersutite series of the BM are mostly chemically homogeneous, with no pronounced $\mathrm{Mg}$-Fe fractionation and zoning. The amphiboles are characterized by relatively homogeneous $\varepsilon \mathrm{Nd}_{(\mathrm{i})}$ $=+1.4$ to +3.8 values: only a single sample from the České Středohoří Volcanic Complex (CSVC) yielded a negative $\varepsilon \mathrm{Nd}_{(\mathrm{i})}(-0.6)$. This testifies to locally elevated proportions of recycled Variscan crustal material during melting of mantle peridotites rich in clinopyroxene-amphibole veins. These veins were formed by metasomatic fluids enriched in High Field Strength Elements (HFSE) and are isotopically similar to Enriched Mantle1 (EM1)-type mantle. Amphibole host rocks occur in areas with a significant concentration of basaltic magmas in rift zones along lithospheric block boundaries of the BM. Lithospheric mantle beneath such zones was probably strongly influenced by metasomatic fluids during the formation of clinopyroxene-amphibole veins in mantle peridotite that facilitated the generation of basaltic magma with amphibole.
\end{abstract}

(c) 2018 Elsevier B.V. All rights reserved.

\section{Introduction}

Hydrous mineral phases have also been recognized in the Earth's upper mantle region (Frost, 2006 and references therein). These

\footnotetext{
* Corresponding author at: Institute of Geology of the Czech Academy of Sciences, Rozvojová 269, 16502 Praha 6, Czech Republic.

E-mail address: lukas.krmicek@gmail.com (L. Krmíček).
}

minerals have, among others, a substantial influence on the origin of primitive magmas (Martin, 2007 and references therein), acting as fundamental sources of water, potassium and titanium essential for their genesis. Amphiboles of kaersutite composition and/or phlogopite are supposed to be the most relevant candidates.

The mineral composition and the chemical character of fertile mantle xenoliths show that they are commonly metasomatically enriched in $\mathrm{K}$, Fe, light rare earth elements (LREE), Ti and other incompatible large 
ion lithophile elements (LILE), together with $\mathrm{H}_{2} \mathrm{O}$ and $\mathrm{CO}_{2}$, thus representing products of cryptic metasomatism as expressed in clinopyroxene and glass compositions, or of modal metasomatism by amphibole and phlogopite crystallization.

\subsection{Stability of amphiboles of the magnesio-hastingsite-pargasite- kaersutite series}

Experimental results show that kaersutite in both water-rich basalts and peridotites (Frost, 2006 and citation therein) is stable at upper mantle $\mathrm{p}-\mathrm{T}$ conditions. A series of publications presented stability data on amphiboles in the temperature range of $1000-1300^{\circ} \mathrm{C}$ and the pressure range of 1.5-3.0 GPa (Green et al., 2010; Pilet et al., 2010). Amphiboles of the pargasite-kaersutite series show a relatively wide range of depth stability, not exceeding the depth of 80-100 km (Class and Goldstein, 1997; Mayer et al., 2013; Robinson and Wood, 1998). Dawson and Smith (1982) presented the as yet not fully resolved question: is kaersutite the source of magma or its product?

\subsection{Paragenesis of amphiboles of the pargasite-kaersutite series}

Wilshire (1987) recognized four fundamental mineral parageneses in mantle xenoliths, two of them associated with mantle metasomatism: (i) mafic water-bearing xenoliths (hornblendite, glimmerite), and (ii) megacrysts (amphibole, phlogopite, clinopyroxene). Amphibole and clinopyroxene megacrysts commonly represent either (i) highpressure cognate phenocrysts (Ellis, 1976 and references therein), or (ii) disrupted fragments of cumulates and/or pegmatitic rocks that formed from mafic magmas (Righter and Carmichael, 1993; Shaw and Eyzaguirre, 2000). Surfaces of the amphibole crystals often indicate corrosion by the host magma and disequilibrium phenomena. Alternatively, the phenocrysts/xenocrysts show perfect crystal faces indicating either an equilibrium with the host basaltic rock at a certain stage of their development or a rapid ascent to the surface.

The chemical composition of amphiboles in mantle xenoliths varies considerably: pargasite is present prevalently in peridotites of the $\mathrm{Cr}$-diopside series, whereas kaersutite is common in pyroxenite and websterite inclusions of the $\mathrm{Al}$-augite series. Most amphiboles in volcanic rocks, including phenocrysts (sensu lato) to megacrysts (discrete nodules), belong to the kaersutite series. They occur together with similar phenocrysts/xenocrysts of clinopyroxene (Al-diopside) and rare Kfeldspar, garnet and ilmenite.

Amphibole and clinopyroxene megacrysts in basalts of the Pannonian Basin, Hungary (Dobosi et al., 2003) represent fragments of cumulates and/or pegmatitic veins that crystallized from basaltic melts at lithospheric mantle conditions of 1.1 to $1.4 \mathrm{GPa}$. Compositions of the calculated hypothetical melts in equilibrium with the megacrysts are similar to those of the host basalts, only the ${ }^{87} \mathrm{Sr} /{ }^{86} \mathrm{Sr}$ ratios of the megacrysts are lower and the ${ }^{143} \mathrm{Nd} /{ }^{144} \mathrm{Nd}$ ratios higher than those of the host rocks. Subsequently, the Sr-Nd isotope-enriched magma passed through older amphibole-bearing intrusions and reached the surface carrying fragments of the earlier amphibole megacrysts.

Similarly, Ubide et al. (2014) explained the two-phase origin of phenocrysts of amphiboles and clinopyroxenes in lamprophyres by the existence of antecrysts in such open systems. The antecrysts are recycled mineral phases which started crystallization at an earlier stage in the same magma plumbing system (Francalanci et al., 2012 and references therein). Their cores crystallized at a depth of ca. $25 \mathrm{~km}$ in a magma chamber that received repeated injections of hydrous magma that mixed with the residual magma, inducing evolved crystallization of mafic macrocrysts.

\section{Geological setting}

The young intraplate alkaline volcanism of the Bohemian Massif (BM) is an integral part of the Late Cretaceous and Cenozoic Central
European Volcanic Province (CEVP, Ziegler, 1994) (see Fig. 1). It is a manifestation of a large, sheet-like region in the upper mantle upwelling (Hoernle et al., 1995) or several passive diapiric upwellings of the partially melted upper mantle in the absence of significant thermal anomalies (Lustrino and Wilson, 2007). CEVP volcanic products are spatially and genetically linked to the European Cenozoic rift system (ECRIS, Dèzes et al., 2004), which evolved in the Variscan-consolidated foreland of the Pyrenean-Alpine thrust front at ca. 37-17 Ma. The origin and evolution of graben structures were largely governed by pulses of compressive stress transmitted from the orogen (Bourgeois et al., 2007).

The heterogeneous subcontinental lithospheric mantle beneath the $\mathrm{BM}$ which had undergone extensive partial melting was subsequently metasomatically affected by fluids and melts associated with the subduction processes of the late stages of the Variscan orogeny (Dostal et al., 2017; Krmíček et al., 2016; Lustrino and Wilson, 2007; Ulrych et al., 2002). The presence of hydrous mineral phases such as amphibole and/or phlogopite in the mantle source accelerated the processes of its partial melting, which were followed by the ascent of mantle-derived magma. The presence of suites of anhydrous xenoliths and hydrous xenoliths with pargasitic amphibole testifies to lithospheric mantle heterogeneity in the CEVP.

Cretaceous and Cenozoic volcanism of the BM shows a broad span of ages ( 81 to $0.26 \mathrm{Ma}$ ), nevertheless, the main pulse of magmatic activity culminated at $32-24 \mathrm{Ma}$ (Ulrych et al., 2011). It was controlled in particular by the ENE-WSW-trending Ohře/Eger Rift (OR), and its products have been preserved in the rift graben whose early evolution was governed by stress fields characteristic for the ECRIS but later by NESW and NW-SE tensional fields typical throughout the BM (Coubal et al., 2015). Volcanic products include lava flows, volcano-sedimentary deposits, dykes, breccia-filled vents, and subvolcanic intrusions. The volcanic rocks are alkaline silica-undersaturated, sodic $\left(\mathrm{Na}_{2} \mathrm{O}>\mathrm{K}_{2} \mathrm{O}\right)$ types, forming two main series: (i) a prevailing basanite-phonolite series, and (ii) a subordinate trachybasalt-trachyte series (Dostal et al., 2017). Mafic rocks strongly predominate over felsic and medium types $(<10 \%)$ in both rock series.

The aim of the study is to establish the variation in bulk and trace element chemical compositions and Sr-Nd isotope characteristics of amphiboles of the kaersutite series from various mineral parageneses and to evaluate their role in the genesis of host alkaline volcanic rocks. The aim is also to obtain information on subcontinental lithospheric mantle metasomatic processes based on thermobarometric studies of amphiboles, and hence contribute to the interpretation of sources of primary magmas.

\section{Sampling and analytical methods}

Amphiboles and their host rocks were sampled at thirty representative sites in the BM. Locations of the sampling points are given in Supplement S1A in the electronic appendix to this paper and in Fig. 1. The amphibole and clinopyroxene fractions were prepared by crushing free crystals to a grain size of 0.125 to $0.250 \mathrm{~mm}$ and by a double centrifugation in a dioxane-methylene iodide medium. The final fraction was $>98-99 \%$ pure. The separated amphibole and clinopyroxene fractions with gravities of 3.22-3.26 and 3.33-3.38 g.cm ${ }^{-3}$, respectively, were used for trace element and isotope study. All specific gravity values were obtained using a suspension method. The mineral separates were leached in strongly diluted $\mathrm{HCl}$ and $\mathrm{HNO}_{3}$ to eliminate contamination.

Major element concentrations of amphiboles were obtained from thin sections of megacrysts and host rocks using a CAMECA SX-100 electron probe microanalyser (EPMA) equipped with four wavelength dispersive X-ray spectrometers, housed at the Institute of Geology of the Czech Academy of Sciences, Praha. Accelerating voltage of $15 \mathrm{kV}$, sample current of $8 \mathrm{nA}$, and the electron beam of $2 \mu \mathrm{m}$ in diameter were applied for all analyses. $K \alpha$ spectrum lines were used for analyses of all elements. The following elements were analysed (standards, spectrometer 


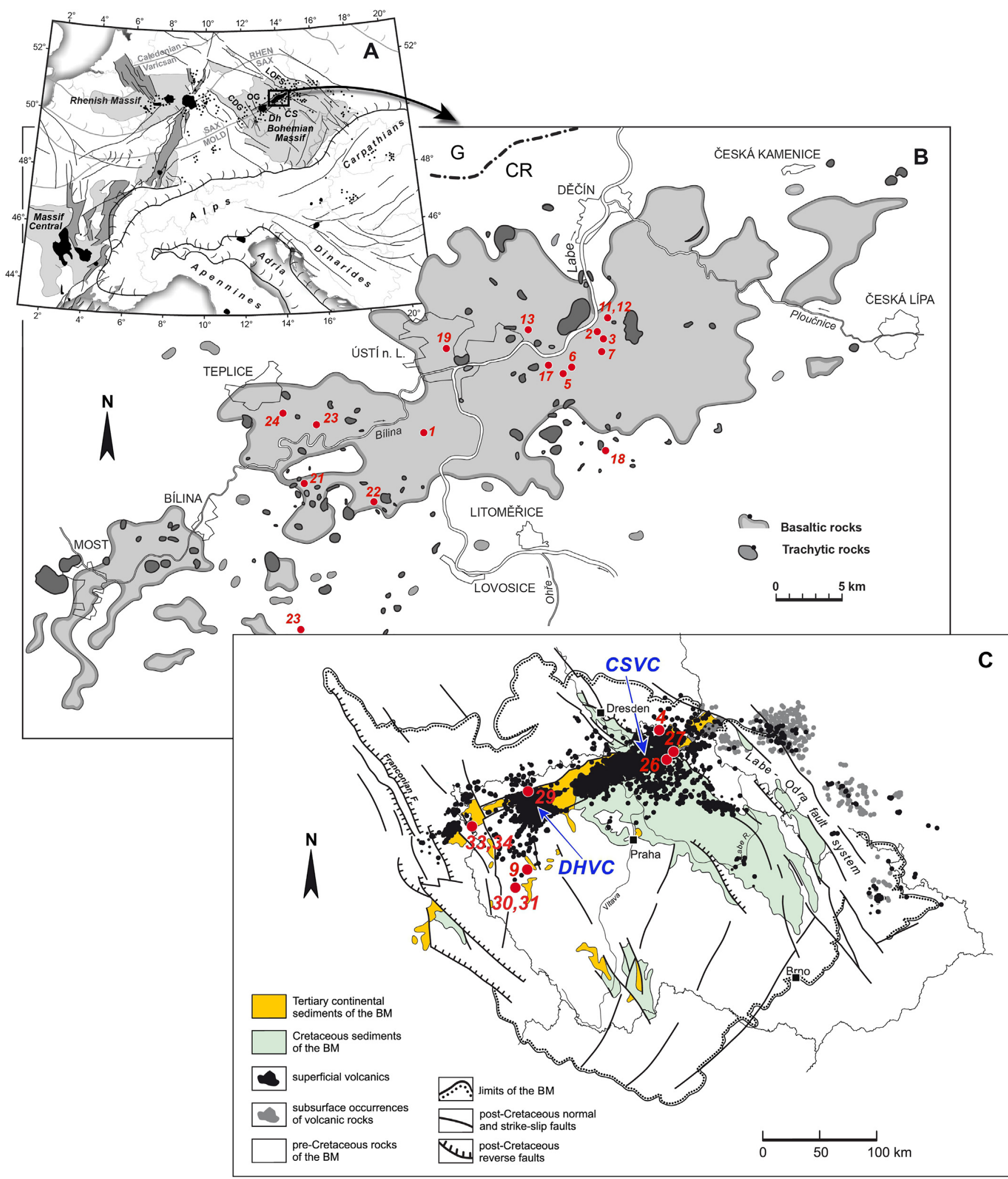

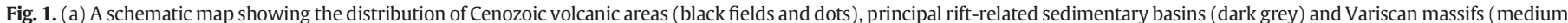

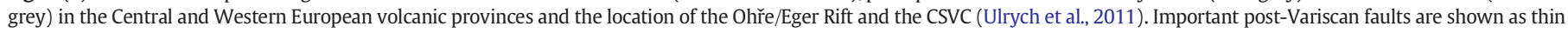

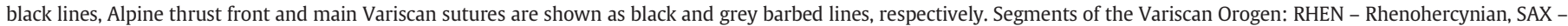

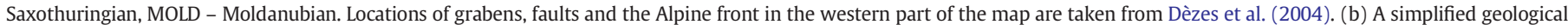

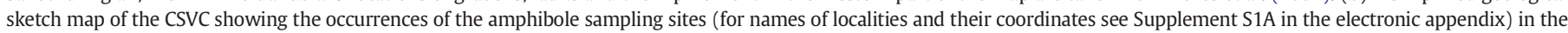

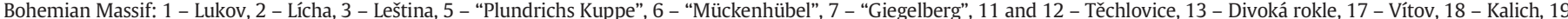

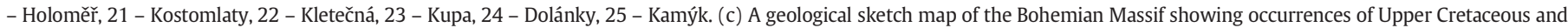

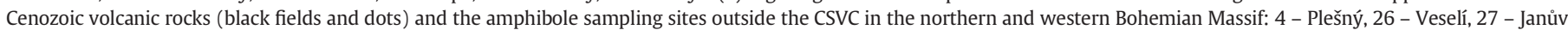
Důl, 29 - Stráž nad Ohří, 30, 31 - Vlčí hora, 33 - Mýtina, 34 - Železná hůrka, 9 - Hradišst’ský kopec. 
crystals and detection limits, respectively, are given in parentheses): $\mathrm{Si}$ (diopside, TAP, 600 ppm), Ti (rutile, LPET, 350 ppm), Al (jadeite, TAP, $590 \mathrm{ppm}$ ), $\mathrm{Cr}\left(\mathrm{Cr}_{2} \mathrm{O}_{3}\right.$, LLIF, 600 ppm), Fe (magnetite, LLIF, 1100 ppm), Mn (rhodonite, LLIF, 900 ppm), Ni (Ni, LLIF, 1100 ppm), Mg (periclase, TAP, 450 ppm), Ca (diopside, LPET, 400 ppm), Na (jadeite, TAP, 890 ppm), K (sanidine, LPET, 300 ppm), P (apatite, LPET, 350 ppm). The X-phi correction procedure was used for spectra processing. Backscattered electron (BSE) images were taken using the Tescan Vega 3XMU scanning electron microscope housed at the Institute of Geology of the Czech Academy of Sciences, Praha, operated at resolution-optimized conditions.

Trace element concentrations were determined using the Thermo Element 2 sector-field ICP-MS at the Institute of Geology of the Czech Academy of Sciences, Praha. In brief, $0.1 \mathrm{~g}$ of sample powder was decomposed in a mixture of $\mathrm{HF}-\mathrm{HClO}_{4}$ acids in open Teflon beakers, the remaining residue was thereafter dissolved using $2 \% \mathrm{HNO}_{3}$ and transferred to a $100 \mathrm{ml}$ volumetric flask. This solution was finally diluted for ICP-MS measurements. Instrumental calibration was performed using aqueous multi-element calibration solutions and ${ }^{115}$ In as an internal standard for the correction of instrumental drift. The accuracy of 5\% was obtained comparing the long-term reproducibility of the USGS reference material BCR-2 against the recommended values (Jochum and Nohl, 2008).

The $\mathrm{Sr}$ and $\mathrm{Nd}$ isotope measurements were performed at the Ludwig-Maximilian-Universität in München on a Spectromat-upgraded MAT 261 in a static data collection mode. Sample powders were dissolved in $\mathrm{HF}-\mathrm{HClO}_{4}$ in PFA closed vessels for 3 days at ca. $90{ }^{\circ} \mathrm{C}$. Sr and Nd were separated using chromatographic procedures as outlined in Hegner et al. (1995). ${ }^{143} \mathrm{Nd} /{ }^{144} \mathrm{Nd}$ were normalized to ${ }^{146} \mathrm{Nd} /{ }^{144} \mathrm{Nd}=$ 0.7219 and $\mathrm{Sr}$ isotopic ratios to ${ }^{86} \mathrm{Sr} /{ }^{88} \mathrm{Sr}=0.1194$. For the period of sample analysis the JNdi- 1 reference material yielded ${ }^{143} \mathrm{Nd} /{ }^{144} \mathrm{Nd}=$ $0.512104 \pm 15(2 \sigma, n=15)$. The NIST NBS987 Sr standard gave ${ }^{87} \mathrm{Sr} /{ }^{86} \mathrm{Sr}=0.710211 \pm 7(2 \sigma, n=6)$. Strontium data were corrected for the machine bias by strontium, by adding 0.000035 to all ratios. Procedural blanks are $<200 \mathrm{pg}$ for Nd which are not significant with respect to sample concentrations.

\section{Results}

\subsection{Samples and petrographic characteristics}

The studied amphiboles occur in numerous parageneses in a wide range of associations/petrographic types of host alkaline magmatic rocks (cf. data in Supplement S1A and S1B in the electronic appendix to this paper):

\section{Type A}

Phenocrysts (1-3 mm) in subvolcanic mafic alkaline rocks forming individual subhedral crystals and rare rims on clinopyroxene phenocrysts in essexite stocks (Lícha stock - sample $\mathbf{2}$ and Leština dyke - sample $\mathbf{3}$ ) in the Roztoky Intrusive Centre (RIC) of the CSVC (Skála et al., 2014).

\section{Type $B$}

Phenocrysts/xenocrysts (1-2 cm) to megacrysts (up to $6 \mathrm{~cm}$ ) in dykes of alkaline lamprophyres associated with the RIC of the CSVC (Skála et al., 2014): camptonite (Těchlovice - sample 12), and maenite with the local name "gauteite" (Těchlovice and Divoká rokle - samples 11, 13). Similar phenocrysts/xenocrysts come from camptonite with the local name "wesselite" from Veselí (sample 26) and camptonite dykes from Janův Důl (sample 27) in northern Bohemia (Ulrych et al., 2014).

Type C

Xenocrysts (1-4 cm) to megacrysts (5-8 cm, max. $12 \mathrm{~cm}$ - Vlčí hora) in alkaline basaltic volcanic rocks occur in (i) basaltic breccia fills of vents (Lukov, Holoměř, Kletečná and Kupa - samples 1, 19, 22, 23), (ii) altered basanitic and tephritic rocks flows, intrusions and tuffs ("Plundrichs
Kuppe”, “Mückenhübel”, Kostomlaty, Dolánky, Kamýk - samples 5, 6, $\mathbf{2 1}, \mathbf{2 4}, \mathbf{2 6}$ ). Xenocrysts to megacrysts come also from the Vlčí hora basanite scoria and lava flow (samples 30, 31), Hradišt'ský kopec tephrite lava flow ( sample 9), and Stráž nad Ohří xenoliths of cumulate from nephelinite lava (sample 29). Amphibole and clinopyroxene xenocrysts in alkali pyroxenite xenoliths were presented by Ulrych et al. (2005) from volcanic breccia of the Loučná-Oberwiesenthal Volcanic Centre, western Bohemia. Amphibole xenocrysts occur in basanites rich in disintegrated peridotite mantle xenoliths at Plešný (sample 4) in northern Bohemia (Ackerman et al., 2015a).

Amphibole xenocrysts are often accompanied by diopside clinopyroxene xenocrysts to megacrysts (up to $5 \mathrm{~cm}$ ) of diopside composition in scoria and lavas (samples $\mathbf{9}, \mathbf{3 0}, \mathbf{3 1}$ ) and tuffs (Vlčí hora sample 36).

\section{Type D}

Xenocrysts, xenoliths (autoliths) of cumulates in felsic massive alkali rocks occur together with clinopyroxene in trachytic and trachyandesitic intrusions (Vítov, Kalich - samples 17, 18; Ackerman et al, 2015b). Voluminous hornblendite to pyroxene hornblendite xenoliths occur in sodalite syenite of "Giegelberg" (sample 7).

\section{Type E}

Primary constituents of mantle xenoliths and xenocrysts to megacrysts in scoria and tephra occur in rare xenoliths of hornblende clinopyroxenite to clinopyroxene hornblendite (Geissler et al., 2007) and in the form of partially melted kaersutite megacrysts $(0.5$ to $4 \mathrm{~cm}$ in size) in tephra of the Plio-Pleistocene Mýtina maar (sample 33) and scoria of the Železná hưrka cinder cone.

The study is focussed on amphiboles of discrete euhedral crystals often set free by weathering of altered basaltic pipe fills (e.g., Lukov, "Mückenhübel"), volcaniclastic products such as tuffs (Fig. 2a), and tephra/scoria deposits of volcanoes and cinder cones (e.g., Vlčí hora, Kletečná, Mýtina-Železná hůrka) and altered porous basaltic rocks (e.g., "Plundrichs Kuppe", Kamýk). Homogeneous crystals with primarily subhedral forms, often broken, are typical for amphiboles in fresh/ unaltered basanitic intrusions (e.g., Kamýk, Vlčí hora). The shapes of perfect amphibole crystals range from short, columnar (Lukov) to long, thinly columnar ("Mückenhübel") and thickly columnar (Vlčí hora).

The text follows the classification of large crystals in rocks by Streck (2008). Larger crystals embedded in finer crystalline groundmass are commonly called phenocrysts (s.l.). Phenocrysts (s.s.) are crystals growing in situ from a magma, while antecrysts are cognate crystals that did not grow from the magma in which they occur. Xenocrysts are crystals derived from various country rocks. Macrocrysts (megacrysts if $>5 \mathrm{~mm}$ ) is a non-genetic term. Cumulate is a magmatic rock formed by the accumulation of crystals implying gravitational setting.

Homogeneous smaller phenocrysts are a characteristic form of amphibole in essexites (e.g., Lícha); rare amphibole rims on diopside phenocrysts were also observed. Amphibole macrocrysts (phenocrysts and xenocrysts) in lamprophyres are subhedral to euhedral, lacking substantial zoning features (e.g., Těchlovice, Fig. 2g). Amphiboles of large xenoliths of cumulates are characterized by subhedral, parallel-elongated thin columns of amphibole (Fig. 2b, "Giegelberg") and thickly columnar amphibole aggregates (Stráž n. O.).

Amphibole crystals only rarely show distinct zoning in an optical microscope (Fig. 2c) and BSE images (Fig. 2e). Only amphiboles of xenoliths of a hornblendite cumulate in sodalite syenite from "Giegelberg" show an indistinct zoning, partly reflected in higher $\mathrm{Mg}$ contents in the cores and Fe contents in the rims (see Supplement S2, analyses 7.1 and 7.2), suggesting some fractionation. A rather subtle difference in the Mg-Fe contents was displayed in amphibole zoning in camptonite/ basanite from Janův Důl (Supplement S2, analyses 27.1 and 27.2). 

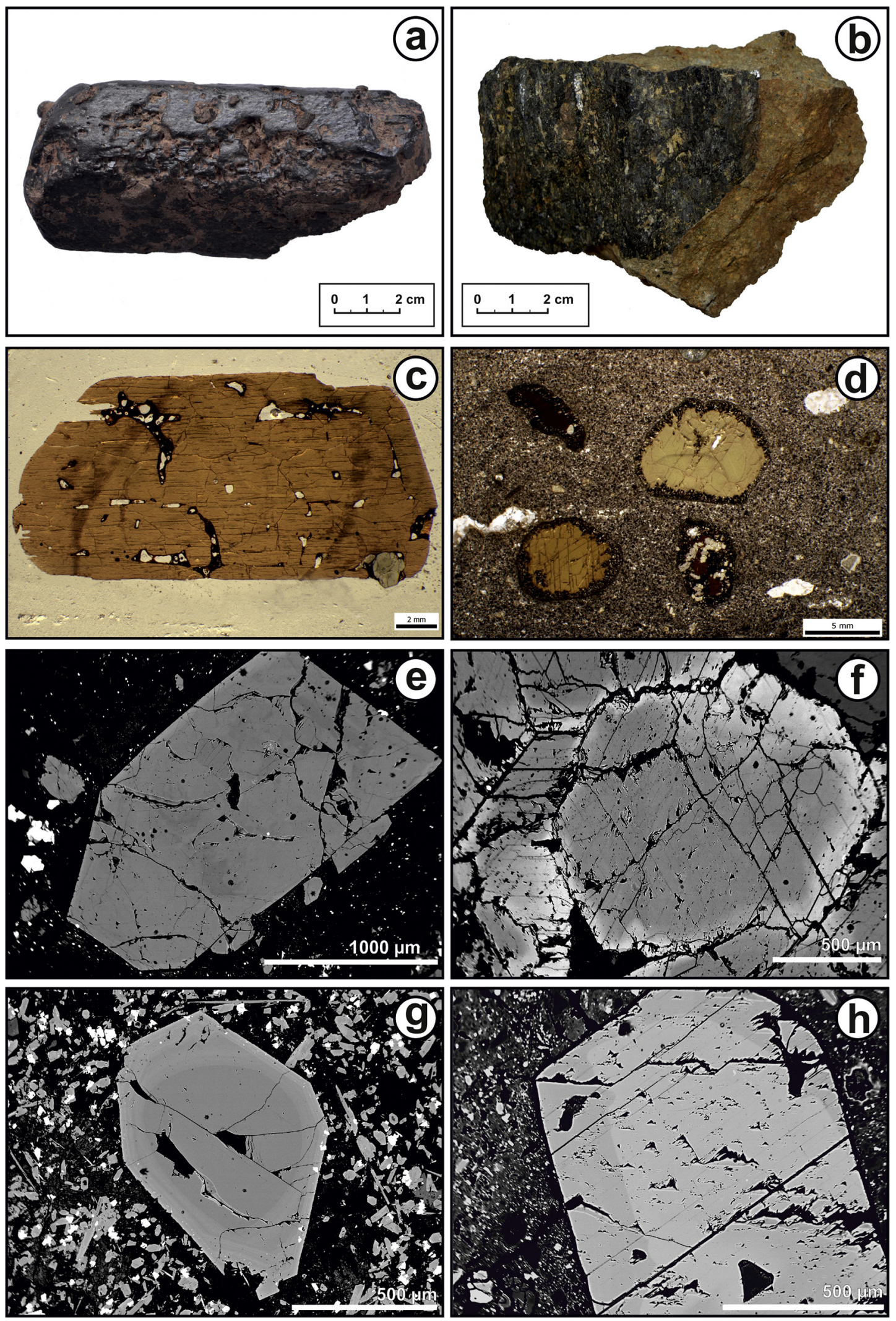

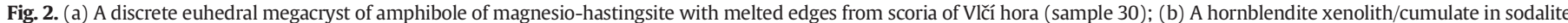

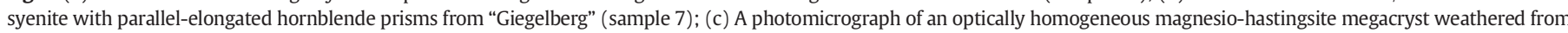

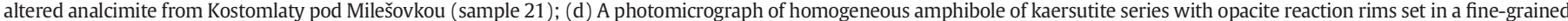

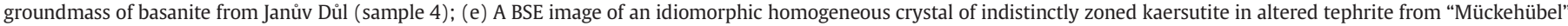

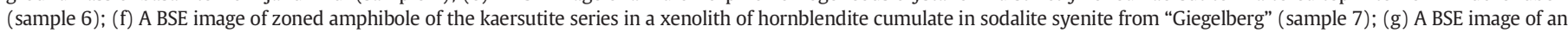

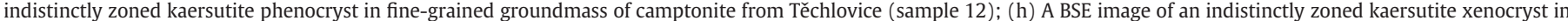
altered basaltic breccia from Kletečná (sample 22). 
Titanian magnetite and magnetite, often growing parallel to amphibole cleavage, form the most common inclusions in all amphiboles. Less common are apatite (Kostomlaty, Vítov, "Giegelberg"), ilmenite (Vítov, Divoká rokle) and diopside (Stráž n.O., Divoká rokle). Very rare inclusions are represented by enstatite, labradorite and alkali feldspar, occurring exclusively in amphibole megacrysts from Vlčí hora.

A disequilibrium is manifested by minor peripheral dissolution and a slight roundness of crystal edges of amphibole megacrysts of xenocrystic character, e.g., from Vlčí hora, "Mückenhübel" and Mýtina. Perfect discrete crystals with no signs of surficial dissolution are characteristic for amphibole xenocrysts, e.g., from Lukov, Holoměř and Kupa. These characteristics are probably connected with a very rapid ascent of lava or with paroxysm during the ascent of volcaniclastic material (cf. Han et al., 2008). Opacite breakdown textures resulting from the disequilibrium between the xenocrystic amphibole and the basaltic groundmass are typically developed at Janův Důl (Fig. 2d). Reaction rims around amphibole crystals progress to affect the entire crystals (De Angelis et al., 2015).

BSE studies supplemented by a set of about 600 electron microprobe analyses of amphiboles revealed a considerable homogeneity (Fig. 2e, g) of the amphibole crystals studied, with only inexpressive/weak zoning (Fig. 2f, h)

We suppose that only amphiboles of rock associations of types A and partly B can be classified to phenocrysts s.s., while types C, D, and E probably represent xenocrysts; the characteristic signs of antecrysts (cf. Ubide et al., 2014) in lamprophyres were not ascertained. However, Streck (2008) pointed to difficulties in classifying individual amphibole megacrysts. Amphibole phenocryts and xenocrysts are mostly homogeneous. The rare indistinct zoning is related to compositional variations from core to rims, which corresponds to a liquid line of descent during cooling (cf. Mayer et al., 2014).
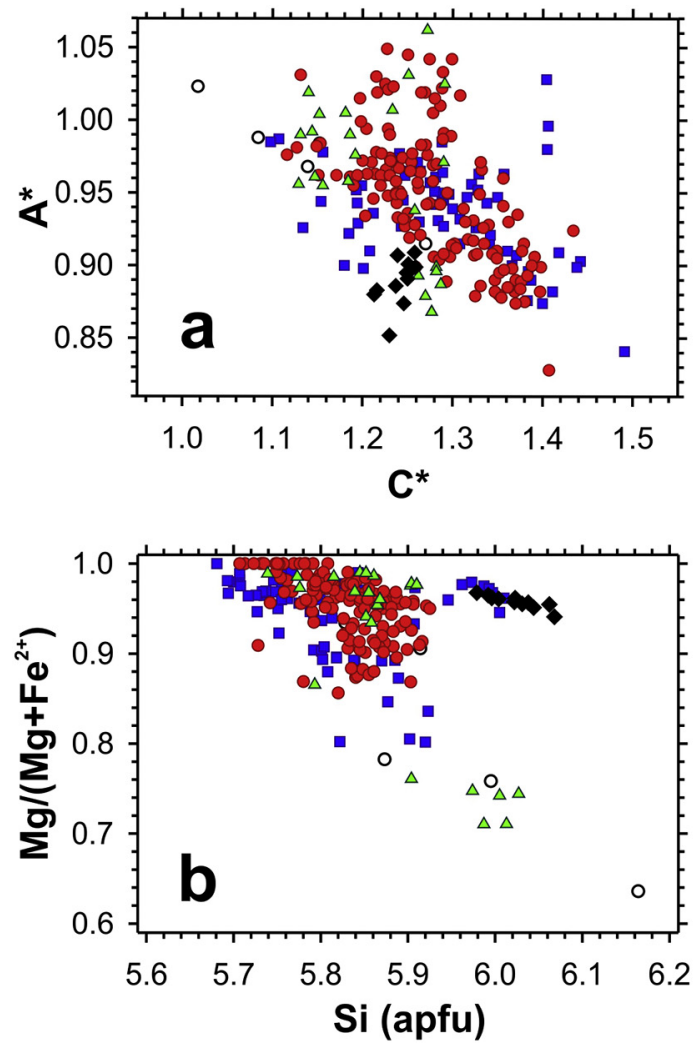

In the studied magmatic rock associations, amphibole is often accompanied by clinopyroxene. Most clinopyroxene crystals are discrete euhedral to subhedral xenocrysts $(0.5$ to $5 \mathrm{~cm})$ often set free by weathering of altered basaltic pipe fills, tuffs, and scoria of volcanoes. However, they were studied only in association with the $\mathrm{Rb}-\mathrm{Sr}$ isotopic study of megacrysts from the site of Vlčí hora (samples 30C, 31C, 36C). They occur as discrete perfect short columnar euhedral megacrysts in scoria and tuff with no signs of dissolution. Subhedral xenolithsmegacrysts are rare in the basanite lava. These clinopyroxenes commonly display only a mild zoning. The site of Hradišt'ský kopec locality (sample 9C) is characterized by subhedral to euhedral megacrysts of clinopyroxene in partly digested xenoliths. These megacryst characteristics are probably associated with the very rapid ascent of lava or paroxysm during the ascent of volcaniclastic material containing both amphibole and clinopyroxene (cf. Han et al., 2008).

\subsection{Major and trace element geochemical characteristics}

4.2.1. Amphiboles of the magnesio-hastingsite-pargasite-kaersutite series

In the classification schemes of both Hawthorne et al. (2012) and Leake et al. (1997), the analysed amphiboles belong to the magnesiohastingsite-pargasite-kaersutite series (Supplement S2; Fig. 3a, b). Compositions of the amphiboles show mostly minor variation from core to rims, from Ti-rich magnesio-hastingsite to ferri-kaersutite, see Supplement S2.

Nevertheless, Ti contents show a moderate variation ( $\sim 0.4$ to $0.6 \mathrm{apfu}$ ) not only within a single site but even within a single megacryst. The cores are rather Ti-poor, formed by magnesiohastingsite and the rims are rather Ti-rich, formed by kaersutite. Amphiboles from the BM, much like those from the Rhön area (Mayer et al., 2014), plot in the marginal part of the field of amphiboles from veined peridotites (Fig. 3c).

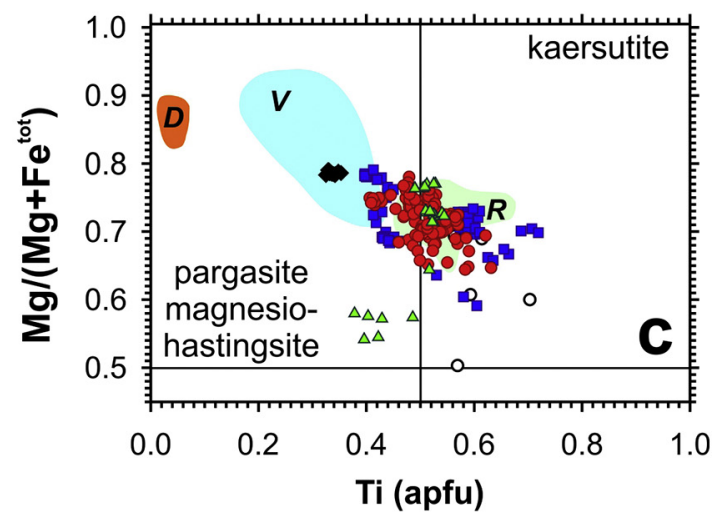

- Petrographic type A - Petrographic type B - Petrographic type C $\triangle$ Petrographic type D - Petrographic type E

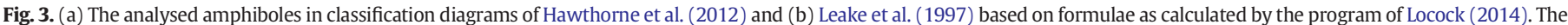

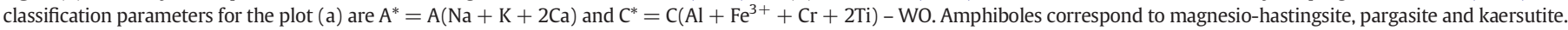

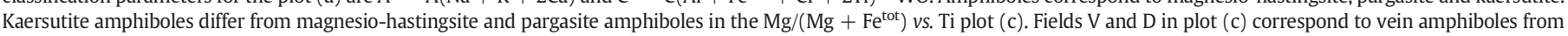

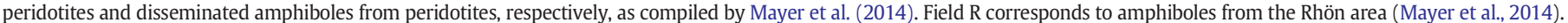


Amphibole macrocrysts are mostly compositionally homogeneous (Supplement S2) with only rare distinct zoning. Nevertheless, amphibole crystals show minor core-rim variations (see Supplement S2, analyses 27.1 and 27.2 from Janův Důl; Fig. 2d). Only amphiboles from a xenolith of hornblendite cumulate (Fig. 2b) in sodalite syenite from "Giegelberg" (type D) show a substantial zoning with concentrations of $\mathrm{Mg}$ in the cores (Supplement S2, analysis 7.1; Fig. 2f) and Fe in the rims (Supplement S2, analysis 7.2; Fig. 2f), suggesting a fractionation. Amphibole from the Lícha essexite (type A) forms mostly homogeneous phenocrysts and rarely thin rims on clinopyroxene phenocrysts. Amphiboles of the kaersutite series from rock association of type E, represented by xenolith sample 33 from Mýtina tephra, are characterized by low Si atoms per formula unit (apfu) contents. Amphiboles from rock associations of types A and D partly differ also in their low Mg and Ti contents. Low Ti contents (apfu) and high $\mathrm{Mg}$ contents are typical for amphibole xenoliths in the rock association of type E (Supplement S2).

The primitive mantle (PM)-normalized incompatible trace element patterns of amphiboles of the BM show distinct $\mathrm{Cs}$, Th, $\mathrm{U}, \mathrm{Pb}$ and $\mathrm{Zr}$ negative anomalies and Ba and Nb-Ta positive anomalies (Fig. 4a; Table 1 and Supplement S3). The LILE and HFSE concentration trends in amphiboles from the BM and the Rhön area (Mayer et al., 2014) are similar to those of amphiboles from peridotite xenoliths (Ionov and Hofmann, 1995; Powell et al., 2004; Witt-Eickschen et al., 2003). The lowest contents of incompatible elements in the amphiboles were found in rock associations of types $\mathrm{C}$ and $\mathrm{E}$ (xenocrysts to megacrysts in alkaline basaltic rocks and xenoliths) followed by type B (phenocrysts/xenocrysts in lamprophyric rocks), type $\mathrm{D}$ (xenocrysts in felsic rocks), and type $\mathrm{A}$ (phenocrysts in subvolcanic rocks), see Fig. 4a. Variations in the contents of compatible elements such as $\mathrm{Sc}, \mathrm{Cr}, \mathrm{V}, \mathrm{Ni}, \mathrm{Co}$ in the amphibole set are relatively small. Substantially differences were found only in amphiboles from the hornblendite xenolith (sample 7 - "Giegelberg"), showing very low $\mathrm{Ni}$ and $\mathrm{Cr}$ contents and in a xenocryst of amphibole of the kaersutite series (sample 33 - Mýtina) characterized by high contents of $\mathrm{Ni}$ and $\mathrm{Cr}$, see Table 1 and Supplement S3.

The chondrite-normalized rare earth element (REE) patterns of amphiboles (Fig. 4b) from basaltic rocks of the BM are generally convex, contrasting with the almost linear pattern of the basaltic host rocks (Fig. 5) that show low to moderate enrichment in light REE (LREE) relative to heavy REE (HREE), as indicated by the $L a_{N} / Y b_{N}$ ratios, see Table 1 and Supplement S3. No Eu anomaly is present. The lowest REE contents in the amphiboles were found in rock associations of types $C$ and E followed by types B, D and A (Fig. 4b), similar to the incompatible element distribution in Fig. 4a.

Chemical analyses of the clinopyroxenes and their trace element contents are presented in Supplement S4. The studied clinopyroxenes are exclusively diopsides in the classification of Morimoto et al. (1988).

\subsubsection{Host rocks}

Petrological characteristics of the twenty-six host rock samples are difficult to evaluate and compare due to the contrasting rock compositions (ultrabasic, intermediate, acid) and rock structures (massive, brecciated, tuffs), particularly with respect to the strong alteration of most rock samples. Volcanic rocks with amphibole megacrysts from the BM are mostly of basaltic composition (Fig. 6; Supplement S5) in the TAS diagram (Le Maitre, 2002).

Variations in the chemical composition of the basaltic rocks are substantial: $\mathrm{SiO}_{2}$ (39.1-44.3 wt\%), $\mathrm{Al}_{2} \mathrm{O}_{3}$ (11.2-15.1 wt\%), $\mathrm{MgO}$ (4.9$13.7 \mathrm{wt} \%), \mathrm{Na}_{2} \mathrm{O}$ (2.0-3.9 wt\%), $\mathrm{K}_{2} \mathrm{O}$ (1.1-3.5 wt\%). Rock compositions are affected by the alteration processes ( $\mathrm{LOI}=8-12 \mathrm{wt} \%$ ) and contamination by volcaniclastic material (in vent breccias) and the presence of disintegrated xenoliths. The basaltic rocks are exclusively sodic with $\mathrm{Na}_{2} \mathrm{O}>\mathrm{K}_{2} \mathrm{O}$. Basaltic rocks usually show high $\mathrm{TiO}_{2}$ concentrations, while altered breccias of trachybasaltic composition usually display lower $\mathrm{TiO}_{2}$ contents, see Supplement S5.

Basaltic host rocks only partly match the criteria for the primary mantle-derived melt sensu Frey et al. (1978). Variations in the Mg\#
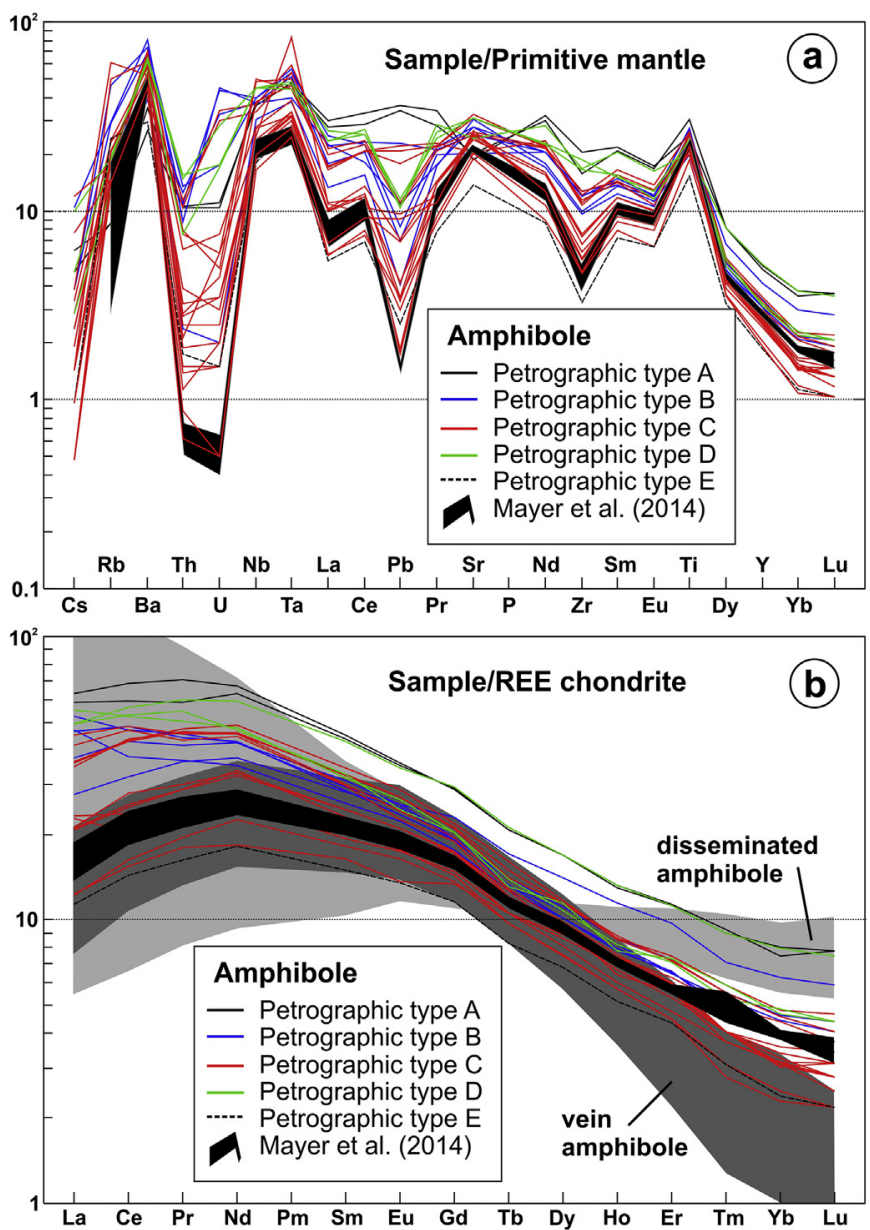

Fig. 4. (a) Primitive mantle-normalized incompatible trace element patterns of amphiboles in rock associations of types A-E. Normalization values were taken from McDonough and Sun (1995). (b) Chondrite-normalized REE patterns of amphiboles in rock associations of types A-E. Normalization values were taken from Boynton (1984). The dark grey field represents vein amphibole from peridotite and the bright grey field disseminated amphibole from peridotite (Ionov and Hofmann, 1995; Powell et al., 2004; Witt-Eickschen et al., 2003).

(45-71) and moderately high contents of compatible elements such as $\mathrm{Cr}, \mathrm{Ni}$, Sc and V are substantial, see Supplement S5. Lherzolite xenoliths were found only in a limited number of samples; they are abundant only in sample 4 - Plešný.

The contents of compatible elements are mostly directly proportional to $\mathrm{MgO}$ contents. The contents of incompatible trace elements, such as $\mathrm{Sr}, \mathrm{Ba}, \mathrm{Y}, \mathrm{Zr}, \mathrm{Hf}, \mathrm{Nb}$ and $\mathrm{Ta}$, show opposite trends relative to $\mathrm{MgO}$ contents. Xenoliths and xenocrysts of the cumulates occur mostly in trachytic rocks (samples 17, 18 and 7).

The almost linear chondrite-normalized REE patterns with negligible Eu anomalies $(\sim 0.9)$ in basaltic rocks show a medium LREE enrichment (Fig. 5) with a fractionation of the LREE with respect to HREE, as indicated by the $\mathrm{La}_{\mathrm{N}} / \mathrm{Yb}_{\mathrm{N}}$ ratios (see Table 1 and Supplement S5) in combination with $\mathrm{Lu}_{\mathrm{N}}$ mostly below 10 . This fractionation reflects melting of deeper garnet-bearing sources. Trachytic rocks have different REE patterns with classic U-shaped forms, and the $\mathrm{La}_{\mathrm{N}} / \mathrm{Yb}_{\mathrm{N}}$ ratios (see Table 1 and Supplement S5).

\section{3. ${ }^{87} \mathrm{Sr} /{ }^{86} \mathrm{Sr}$ and ${ }^{143} \mathrm{Nd} /{ }^{144} \mathrm{Nd}$ isotopic systematics}

\subsubsection{Amphiboles of the magnesio-hastingsite-pargasite-kaersutite series}

The initial $\varepsilon N d$ values of amphibole samples from the BM lie in a very narrow range of $\varepsilon \mathrm{Nd}_{(\mathrm{i})}=+1.4$ to +3.8 , see Table 2 and Fig. 7. Only one kaersutite sample (sample 1 - Lukov) shows a slightly lower $\varepsilon \mathrm{Nd}_{(\mathrm{i})}$ 
Table 1

Trace element contents of representative amphiboles from volcanic rocks of the Bohemian Massif.

\begin{tabular}{|c|c|c|c|c|c|c|c|c|c|c|c|c|c|c|c|c|c|c|}
\hline \multicolumn{19}{|l|}{ Amphibole } \\
\hline Sample No. & 2 & 11 & 26 & 27 & 1.2 & 5.1 & 6 & 19 & 21.1 & 24 & 25 & 4 & 22 & 29.1 & 30.1 & 7.1 & 18 & 33 \\
\hline Locality & Lícha & Těchlovice & Veselí & Janův Důl & Lukov & “Plundrichs K." & “Mückenhübel” & Holoměř & Kostomlaty & Dolánky & Kamýk & Plešný & Kletečná & Stráž n. O. & Vlčí hora & "Giegelberg" & Kalich & Mýtina \\
\hline Rock type & E & GA & CA & CA & BA lava & TE breccia & TE breccia & BA breccia & BA xenocryst & BA & BA & BA & BA breccia & BA xenocr. & BA scoria & $\mathrm{H}$ in $\mathrm{SS}$ & TA & OM tephra \\
\hline Petrogr. type & A & B & B & B & C & C & C & C & C & C & C & C & C & C & C & D & D & $\mathrm{E}$ \\
\hline $\mathrm{Zr}(\mathrm{ppm})$ & 166 & 101 & 127 & 126 & 59.2 & 113 & 116 & 70.3 & 58.0 & 58.1 & 63.9 & 46.4 & 79.2 & 133 & 58.7 & 176 & 174 & 34.3 \\
\hline $\mathrm{Nb}$ & 25.0 & 24.5 & 26.2 & 24.5 & 12.8 & 32.2 & 25.0 & 14.8 & 14.3 & 18.5 & 12.4 & 18.2 & 15.7 & 24.2 & 14.0 & 29.7 & 29.7 & 11.9 \\
\hline $\mathrm{Hf}$ & 6.03 & 3.61 & 4.57 & 4.80 & 2.64 & 4.71 & 4.74 & 3.66 & 2.56 & 2.38 & 2.98 & 1.93 & 3.52 & 5.44 & 2.67 & 6.55 & 6.22 & 1.65 \\
\hline $\mathrm{Ta}$ & 1.73 & 1.48 & 2.09 & 1.90 & 0.97 & 1.85 & 1.71 & 1.19 & 1.17 & 1.42 & 1.05 & 1.19 & 1.25 & 2.19 & 1.12 & 1.63 & 1.75 & 1.00 \\
\hline $\mathrm{Y}$ & 21.0 & 13.3 & 12.5 & 17.8 & 9.23 & 14.3 & 14.0 & 11.6 & 11.2 & 10.7 & 8.80 & 12.9 & 11.1 & 11.7 & 11.4 & 22.4 & 13.4 & 7.98 \\
\hline La & 18.2 & 14.5 & 14.4 & 11.6 & 6.24 & 10.8 & 11.1 & 6.45 & 5.73 & 7.23 & 5.65 & 3.84 & 6.62 & 14.0 & 5.18 & 15.3 & 15.3 & 3.51 \\
\hline $\mathrm{Ce}$ & 48.0 & 30.6 & 39.0 & 34.6 & 20.0 & 35.1 & 34.7 & 20.2 & 17.9 & 19.3 & 17.5 & 12.5 & 22.6 & 39.2 & 17.4 & 45.4 & 42.9 & 11.6 \\
\hline $\operatorname{Pr}$ & 7.20 & 4.48 & 5.36 & 5.06 & 3.39 & 5.61 & 5.65 & 3.53 & 3.12 & 2.96 & 3.01 & 2.21 & 3.66 & 5.57 & 3.06 & 7.34 & 6.70 & 1.99 \\
\hline $\mathrm{Nd}$ & 37.7 & 21.2 & 25.7 & 25.5 & 16.4 & 27.6 & 27.4 & 19.6 & 16.9 & 15.3 & 16.3 & 11.1 & 19.9 & 27.3 & 16.9 & 35.7 & 28.2 & 10.9 \\
\hline Sm & 8.50 & 5.02 & 5.58 & 6.07 & 4.24 & 6.34 & 6.35 & 4.69 & 4.27 & 3.79 & 3.98 & 3.20 & 4.80 & 5.85 & 4.38 & 8.36 & 6.36 & 2.92 \\
\hline $\mathrm{Eu}$ & 2.58 & 1.64 & 1.73 & 1.88 & 1.38 & 2.00 & 2.00 & 1.45 & 1.43 & 1.29 & 1.30 & 1.00 & 1.55 & 1.78 & 1.46 & 2.52 & 1.80 & 0.99 \\
\hline $\mathrm{Gd}$ & 7.56 & 4.58 & 4.97 & 6.00 & 3.85 & 5.51 & 5.46 & 4.49 & 4.15 & 3.85 & 3.72 & 3.47 & 4.54 & 5.06 & 4.37 & 7.63 & 5.31 & 2.99 \\
\hline $\mathrm{Tb}$ & 0.99 & 0.60 & 0.63 & 0.81 & 0.52 & 0.71 & 0.67 & 0.60 & 0.54 & 0.50 & 0.46 & 0.50 & 0.57 & 0.61 & 0.56 & 1.01 & 0.62 & 0.39 \\
\hline Dy & 5.47 & 3.26 & 3.28 & 4.52 & 2.40 & 3.68 & 3.70 & 2.88 & 2.88 & 2.78 & 2.42 & 2.85 & 2.95 & 3.16 & 3.06 & 5.45 & 3.71 & 2.19 \\
\hline Ho & 0.95 & 0.57 & 0.56 & 0.82 & 0.42 & 0.61 & 0.63 & 0.48 & 0.50 & 0.50 & 0.41 & 0.53 & 0.50 & 0.54 & 0.53 & 0.95 & 0.56 & 0.37 \\
\hline $\mathrm{Er}$ & 2.39 & 1.36 & 1.38 & 2.04 & 1.00 & 1.52 & 1.50 & 1.11 & 1.16 & 1.17 & 0.94 & 1.32 & 1.17 & 1.26 & 1.25 & 2.37 & 1.54 & 0.91 \\
\hline $\mathrm{Tm}$ & 0.30 & 0.17 & 0.15 & 0.23 & 0.11 & 0.18 & 0.18 & 0.13 & 0.13 & 0.13 & 0.10 & 0.16 & 0.13 & 0.13 & 0.13 & 0.29 & 0.19 & 0.10 \\
\hline $\mathrm{Yb}$ & 1.56 & 0.92 & 0.83 & 1.31 & 0.58 & 0.95 & 0.95 & 0.63 & 0.68 & 0.71 & 0.52 & 0.91 & 0.64 & 0.74 & 0.71 & 1.65 & 0.97 & 0.50 \\
\hline Lu & 0.25 & 0.13 & 0.12 & 0.19 & 0.08 & 0.13 & 0.13 & 0.10 & 0.09 & 0.10 & 0.07 & 0.12 & 0.09 & 0.11 & 0.10 & 0.24 & 0.14 & 0.07 \\
\hline $\mathrm{Sc}$ & 61.2 & 74.8 & 70.2 & 51.8 & 72.7 & 65.3 & 67.2 & 72.2 & 64.6 & 77.2 & 55.1 & 50.2 & 61.0 & 72.6 & 66.3 & 47.1 & 72.6 & 52.8 \\
\hline V & 312 & 490 & 350 & 348 & 498 & 374 & 361 & 412 & 489 & 510 & 439 & 495 & 433 & 384 & 461 & 454 & 368 & 465 \\
\hline $\mathrm{Cr}$ & 140 & 219 & 329 & 182 & 190 & 272 & 354 & 688 & 215 & 385 & 302 & 110 & 399 & 9.20 & 168 & 22.2 & 119 & 1558 \\
\hline Co & 36.1 & 55.1 & 44.8 & 42.2 & 66.1 & 54.9 & 54.2 & 51.5 & 60.7 & 50.1 & 56.2 & 58.3 & 53.4 & 62.0 & 50.9 & 37.5 & 52.0 & 51.3 \\
\hline $\mathrm{Ni}$ & 68.3 & 158 & 112 & 78.9 & 175 & 126 & 188 & 251 & 189 & 205 & 174 & 263 & 206 & 65.2 & 115 & 13.5 & 136 & 352 \\
\hline $\mathrm{Cu}$ & 14.8 & 38.0 & 11.6 & 11.2 & 27.4 & 29.3 & 6.09 & 9.82 & 16.4 & 10.3 & 26.1 & 70.1 & 4.59 & 158 & 52.2 & 30.6 & 15.0 & 2.60 \\
\hline $\mathrm{Zn}$ & 48.6 & 38.6 & 32.1 & 42.6 & 34.8 & 50.5 & 45.1 & 28.9 & 27.0 & 27.5 & 27.1 & 36.6 & 31.6 & 42.5 & 24.3 & 68.2 & 63.2 & 24.4 \\
\hline $\mathrm{Rb}$ & 5.20 & 17.7 & 27.9 & 10.5 & 14.0 & 9.30 & 10.4 & 10.3 & 11.0 & 36.6 & 14.0 & 9.13 & 14.2 & 10.6 & 9.04 & 7.90 & 11.3 & 14.5 \\
\hline $\mathrm{Sr}$ & 403 & 557 & 510 & 405 & 434 & 618 & 651 & 595 & 506 & 436 & 435 & 377 & 497 & 523 & 494 & 487 & 615 & 274 \\
\hline Cs & 0.10 & 0.22 & 0.08 & 0.05 & 0.03 & 0.03 & 0.05 & 0.03 & 0.02 & 0.08 & 0.07 & 0.01 & 0.04 & 0.25 & 0.01 & 0.06 & 0.10 & 0.02 \\
\hline $\mathrm{Ba}$ & 232 & 530 & 486 & 255 & 351 & 432 & 452 & 409 & 293 & 346 & 275 & 271 & 379 & 263 & 292 & 365 & 412 & 197 \\
\hline $\mathrm{Pb}$ & 5.10 & 1.64 & 3.43 & 1.04 & 0.45 & 3.14 & 2.67 & 0.62 & 0.28 & 0.63 & 0.50 & 0.52 & 1.06 & 1.67 & 1.44 & 1.58 & 1.57 & 0.38 \\
\hline Th & 0.83 & 0.70 & 1.09 & 1.01 & 0.33 & 0.63 & 0.23 & 0.26 & 0.15 & 0.50 & 0.22 & 0.12 & 0.20 & 0.84 & 0.11 & 0.60 & 1.19 & 0.14 \\
\hline U & 0.21 & 0.90 & 0.35 & 0.65 & 0.10 & 0.10 & 0.09 & 0.07 & 0.04 & 0.15 & 0.07 & 0.03 & 0.05 & 0.68 & 0.03 & 0.34 & 0.57 & 0.03 \\
\hline$\sum$ REE & 142 & 89 & 104 & 101 & 61 & 101 & 100 & 66 & 59 & 60 & 56 & 44 & 70 & 105 & 59 & 134 & 114 & 39 \\
\hline $\mathrm{La}_{\mathrm{N}} / \mathrm{Yb}_{\mathrm{N}}$ & 7.9 & 10.6 & 11.7 & 6.0 & 7.3 & 7.7 & 7.9 & 6.9 & 5.7 & 6.9 & 7.3 & 2.8 & 7.0 & 12.8 & 4.9 & 6.3 & 10.6 & 4.7 \\
\hline $\mathrm{Eu} / \mathrm{Eu}^{*}$ & 0.98 & 1.05 & 1.00 & 0.95 & 1.04 & 1.03 & 1.04 & 0.97 & 1.04 & 1.03 & 1.03 & 0.92 & 1.02 & 1.00 & 1.02 & 0.96 & 0.95 & 1.02 \\
\hline
\end{tabular}

BA - basanite, TE - tephrite, E - essexite, $\mathrm{H}$ - hornblendite, SS - sodalite syenite, CA - camptonite, GA - gauteite, TA - trachyandesite, OM - olivine melilitite.

Petrographic types: A - phenocrysts in subvolcanic rocks, B - phenocrysts/xenocrysts in lamprophyric rocks, C - xenocrysts in alkaline basaltic rocks, D - xenocrysts/cumulates in felsic rocks, E - mantle xenoliths and megacrysts.

* Calculated value. 


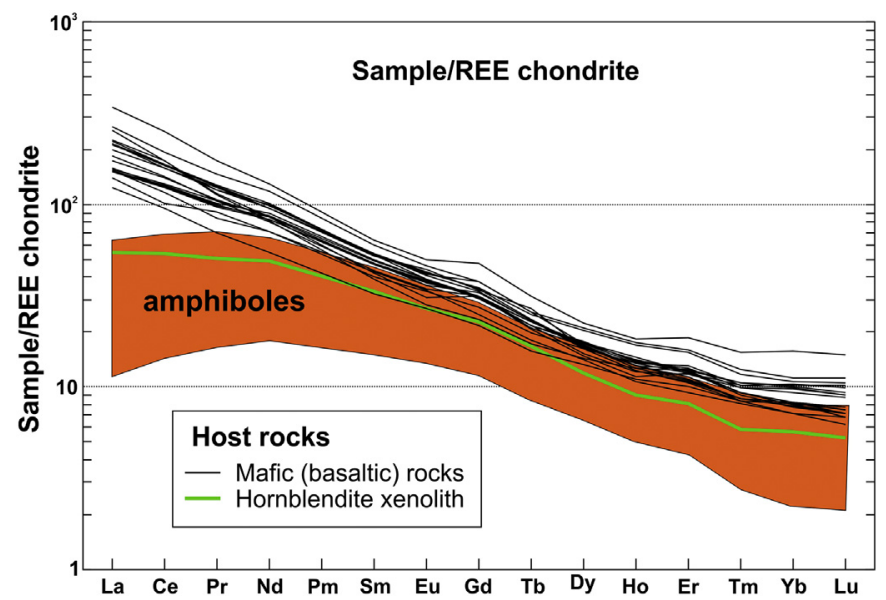

Fig. 5. Chondrite-normalized REE patterns of amphiboles (orange field) and host rocks. Normalization values were taken from Boynton (1984).

value of -0.6 , Table 2 and Fig. 7. This kaersutite sample is characterized by very low REE, Y, Zr, Hf, Nb, Ta, Pb, U and Th concentrations and high $\mathrm{Rb}$ contents (see Table 1; Supplement S3). However, similar geochemical characteristics are also displayed by five other amphibole samples of the rock association of type C (samples 4 - Plešný, 21 - Kostomlaty, 33A - Mýtina, 30 and 31 - Vlčí hora, 9A - Hradišt'ský kopec) which, however, do not show negative $\varepsilon N d$ values.

The initial ${ }^{87} \mathrm{Sr} /{ }^{86} \mathrm{Sr}$ ratios of amphibole samples from the BM show a wider range ( 0.70328 and 0.70407$)$, similar to that of the host rocks from the BM, see Figs. 7 and 8. This reflects either a variation in isotopic composition of the mantle source or an assimilation of material with more radiogenic Sr isotope composition during magma ascent.

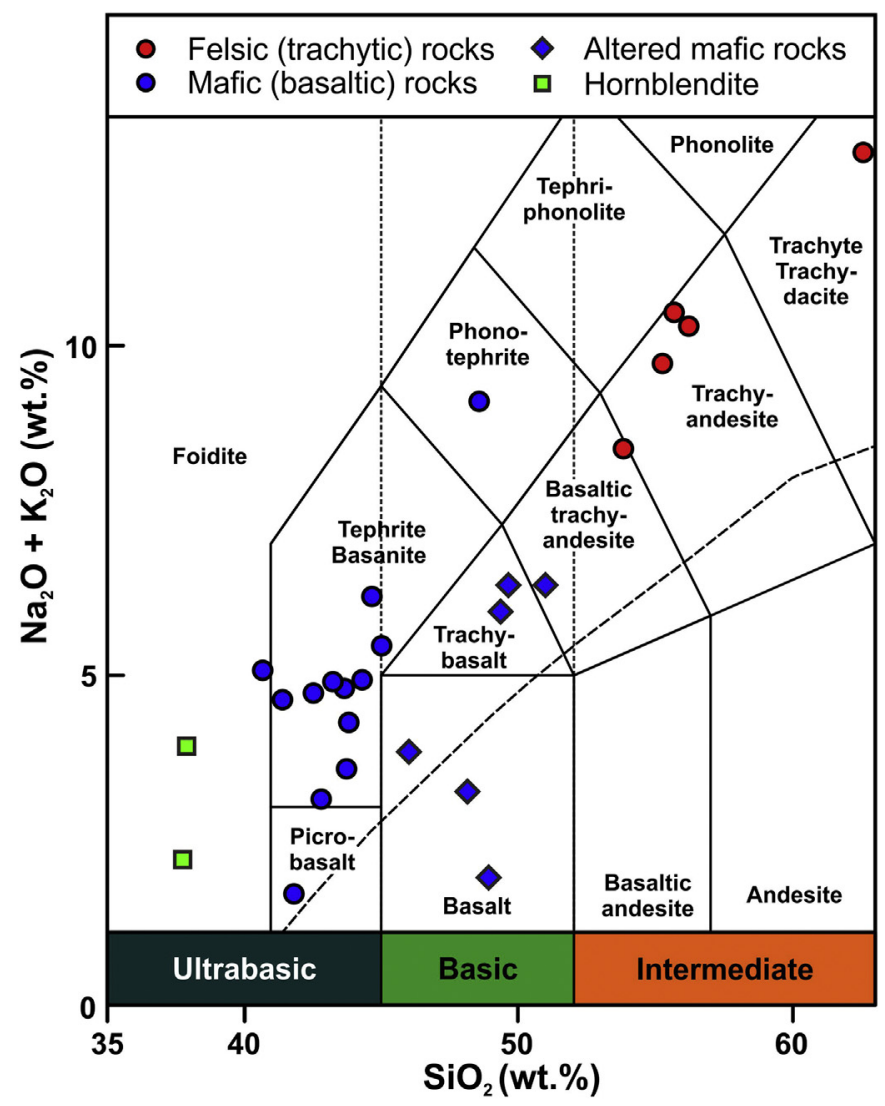

Fig. 6. The TAS diagram (Le Maitre, 2002) showing the composition of amphibole host rocks.
In general, the $\mathrm{Nd}$ and $\mathrm{Sr}$ isotopic compositions of amphiboles of the kaersutite series are independent of the petrographic character of the host rock and the location in the BM (Fig. 7 - Ulrych et al., 2005, 2011) and lie within, or overlap with, the range for the CEVP volcanic rocks (Lustrino and Wilson, 2007).

Initial Sr-Nd isotope data of clinopyroxenes from Vlčí hora (samples $30,31,36$ ) and Hradišt'ský kopec (sample 9), see Table 2, are similar to those of amphiboles from the same localities: $\varepsilon \mathrm{Nd}_{(\mathrm{i})}=+2.4$ to +3.8 and ${ }^{87} \mathrm{Sr} /{ }^{86} \mathrm{Sr}_{(\mathrm{i})}=0.70334$ to 0.70355 (see Fig. 7).

\subsubsection{Host rocks}

The studied amphibole host rocks plot in the field near the Bulk Silicate Earth (BSE) close to the position of the European Asthenospheric Reservoir (EAR) (Lustrino and Wilson, 2007), see Fig. 8. Similar initial Sr-Nd isotopic data are characteristic for the majority of primary mafic Cenozoic volcanic rocks of the BM (Ulrych et al., 2011) and the whole CEVP (Lustrino and Wilson, 2007). Primary mafic rocks from western Bohemia (Ulrych et al., 2016), and northern Bohemia (Ulrych et al., 2008) and those from the CSVC (Ulrych et al., 2002) are characterized by largely similar isotopic ratios, see Fig. 8 .

The studied set of amphibole host rocks is characterized by $\mathrm{Sr}-\mathrm{Nd}$ isotope ratios, very similar to those of the Cenozoic volcanic rocks of the BM (Ulrych et al., 2008, 2011), see Fig. 8.

\section{Discussion}

\subsection{Metasomatic processes}

Three major types of metasomatic patterns have been recorded by Ackerman and Medaris Jr. (2017) in mantle xenoliths of the BM: (i) silicate (basaltic) melt metasomatism, (ii) (alkaline)-silicate melt Femetasomatism, and (iii) metasomatism by carbonatitic-silicate melts in mantle xenoliths, as indicated by large-scale chromatographic fractionation and HFSE depletion recorded in clinopyroxenes. Based on these data, the lithospheric mantle seems to be compositionally heterogeneous beneath the OR. While the central part of the rift was metasomatized by silicate melts of basaltic composition at high melt/ rock ratios, the terminal NE and SW parts of the rift underwent metasomatism by more evolved melts of alkaline and/or alkaline/carbonatitic composition.

Amphibole phenocrysts, xenocrysts, xenoliths of cumulates and their host rocks are genetically associated with metasomatically veined lithospheric mantle rich in (amphibole-bearing) pyroxenite and hornblendite veins. The veins are products of metasomatism of peridotites by fluids enriched in HFSE and originated from EM1-type mantle (Mayer et al., 2014; Witt-Eickschen et al., 2003) associated with metasomatic processes related to the late Variscan subduction events in the BM.

Published data for kaersutites from hornblende-bearing basaltic rocks from the Rhön area (Mayer et al., 2013) and those for vein and disseminated amphiboles from peridotite mantle xenoliths (Ionov and Hofmann, 1995; Powell et al., 2004; Witt-Eickschen et al., 2003) were used for comparison with amphiboles from volcanic rocks of the BM. Amphiboles of the BM and the Rhön area (Mayer et al., 2013) have partly higher $\mathrm{TiO}_{2}$, FeO and $\mathrm{K}_{2} \mathrm{O}$ concentrations but lower $\mathrm{MgO}, \mathrm{Na}_{2} \mathrm{O}$ and $\mathrm{SiO}_{2}$ concentrations compared to the amphiboles from peridotite xenoliths (Ionov and Hofmann, 1995; Powell et al., 2004; WittEickschen et al., 2003).

Geochemistry of basaltic host rocks of the studied amphiboles corresponds to that of Cenozoic alkaline rocks of the BM (Ulrych et al., 2011) and the CEVP (Lustrino and Wilson, 2007) in their common enrichment in highly and moderately incompatible elements (Supplement S5), with an enrichment in light LREE relative to heavy HREE.

Amphiboles of the kaersutite series from alkaline volcanic rocks of the BM and the Rhön area (Mayer et al., 2014) show very similar distributions of incompatible trace elements (Fig. 4a). Moreover, the 
Table 2

Isotope composition of amphibole and clinopyroxene from volcanic rocks of the Bohemian Massif.

\begin{tabular}{|c|c|c|c|c|c|c|c|c|c|c|c|c|}
\hline Sample No. and locality & $\begin{array}{l}\text { Age } \\
(\mathrm{Ma})\end{array}$ & $\begin{array}{l}\mathrm{Rb} \\
\mathrm{ppm}\end{array}$ & $\begin{array}{l}\mathrm{Sr} \\
\mathrm{ppm}\end{array}$ & ${ }^{87} \mathrm{Rb} /{ }^{86} \mathrm{Sr}$ & ${ }^{87} \mathrm{Sr} /{ }^{86} \mathrm{Sr}$ & ${ }^{87} \mathrm{Sr} /{ }^{86} \mathrm{Sr}(\mathrm{t})$ & $\begin{array}{l}\mathrm{Nd} \\
\mathrm{ppm}\end{array}$ & $\begin{array}{l}\mathrm{Sm} \\
\mathrm{ppm}\end{array}$ & ${ }^{147} \mathrm{Sm} /{ }^{144} \mathrm{Nd}$ & ${ }^{143} \mathrm{Nd} /{ }^{144} \mathrm{Nd}$ & ${ }^{143} \mathrm{Nd} /{ }^{144} \mathrm{Nd}(\mathrm{t})$ & $\varepsilon N d(t)$ \\
\hline \multicolumn{13}{|l|}{ Amphibole } \\
\hline \multicolumn{13}{|l|}{ České Středohoří Mts. } \\
\hline 1.1. Lukov & 30 & 12.5 & 400 & 0.090 & $0.703556 \pm 9$ & 0.70352 & 13.5 & 3.55 & 0.1589 & $0.512592 \pm 9$ & 0.51256 & -0.6 \\
\hline 2. Lícha & 30 & 10.4 & 197 & 0.153 & $0.704132 \pm 11$ & 0.70407 & 68.4 & 13.8 & 0.1219 & $0.512685 \pm 7$ & 0.51266 & 1.4 \\
\hline 3. Leština & 30 & 5.1 & 374 & 0.039 & $0.703406 \pm 11$ & 0.70339 & 40.1 & 8.80 & 0.1326 & $0.512697 \pm 6$ & 0.51267 & 1.5 \\
\hline 5.1. "Plundrichs Kuppe" & 30 & 9.3 & 618 & 0.044 & $0.703865 \pm 9$ & 0.70385 & 27.6 & 6.34 & 0.1388 & $0.512713 \pm 7$ & 0.51269 & 1.8 \\
\hline 5.2. "Plundrichs Kuppe"a & 30 & 9.8 & 632 & 0.045 & $0.703884 \pm 11$ & 0.70386 & 27.01 & 6.29 & 0.1407 & $0.512816 \pm 13$ & 0.51279 & 3.8 \\
\hline 6. "Mückenhübel” & 30 & 10.4 & 651 & 0.046 & $0.703859 \pm 9$ & 0.70384 & 27.4 & 6.35 & 0.1400 & $0.512731 \pm 7$ & 0.5127 & 2.2 \\
\hline 7.1. "Giegelberg Hill” & 30 & 7.9 & 487 & 0.047 & $0.704082 \pm 9$ & 0.70406 & 35.7 & 8.36 & 0.1415 & $0.512704 \pm 7$ & 0.51268 & 1.7 \\
\hline 7.2. "Giegelberg Hill”a & 30 & 7.7 & 486 & 0.045 & $0.704098 \pm 12$ & 0.70408 & 35.6 & 8.65 & 0.1468 & $0.512751 \pm 13$ & 0.51272 & 2.5 \\
\hline 7.3. "Giegelberg Hill"a & 30 & 7.7 & 495 & 0.046 & $0.704088 \pm 10$ & 0.70407 & 36.8 & 8.10 & 0.1331 & $0.512755 \pm 13$ & 0.51273 & 2.7 \\
\hline 12. Těchlovice & 30 & 9.3 & 611 & 0.044 & $0.703595 \pm 11$ & 0.70358 & 22.4 & 5.50 & 0.1484 & $0.512782 \pm 8$ & 0.51275 & 3.1 \\
\hline 13. Divoká rokle & 30 & 17.5 & 552 & 0.092 & $0.703775 \pm 9$ & 0.70374 & 25.5 & 5.76 & 0.1365 & $0.512755 \pm 9$ & 0.51273 & 2.7 \\
\hline 17. Vítov & 30 & 11.6 & 620 & 0.054 & $0.703710 \pm 8$ & 0.70369 & 28.7 & 6.17 & 0.1299 & $0.512746 \pm 7$ & 0.51272 & 2.5 \\
\hline 19. Holoměř & 30 & 10.3 & 595 & 0.050 & $0.703547 \pm 11$ & 0.70353 & 19.6 & 4.69 & 0.1445 & $0.512800 \pm 12$ & 0.51277 & 3.5 \\
\hline 21.1. Kostomlaty p. M. (xenocryst) & 30 & 11.0 & 506 & 0.063 & $0.703456 \pm 9$ & 0.70343 & 16.9 & 4.27 & 0.1527 & $0.512764 \pm 8$ & 0.51273 & 2.8 \\
\hline 21.2. Kostomlaty p. M. (megacryst) & 30 & 7.9 & 529 & 0.043 & $0.703515 \pm 7$ & 0.7035 & 15.8 & 4.15 & 0.1587 & $0.512775 \pm 8$ & 0.51274 & 3.0 \\
\hline 22. Kletečná & 30 & 14.2 & 497 & 0.083 & $0.703684 \pm 10$ & 0.70365 & 19.9 & 3.66 & 0.1111 & $0.512752 \pm 9$ & 0.51273 & 2.7 \\
\hline 23. Kupa & 30 & 12.4 & 475 & 0.076 & $0.703644 \pm 9$ & 0.70361 & 19.4 & 3.54 & 0.1103 & $0.512739 \pm 7$ & 0.51272 & 2.5 \\
\hline 24. Dolánky & 30 & 36.6 & 436 & 0.243 & $0.703459 \pm 8$ & 0.70336 & 15.3 & 2.96 & 0.1169 & $0.512782 \pm 7$ & 0.51276 & 3.3 \\
\hline \multicolumn{13}{|l|}{ Northern Bohemia } \\
\hline 26. Veselí & 30 & 28.0 & 510 & 0.159 & $0.703866 \pm 14$ & 0.7038 & 25.7 & 5.58 & 0.1312 & $0.512748 \pm 8$ & 0.51272 & 2.5 \\
\hline 27. Janův Důl & 30 & 10.5 & 405 & 0.075 & $0.703331 \pm 8$ & 0.7033 & 25.5 & 6.07 & 0.1438 & $0.512778 \pm 6$ & 0.51275 & 3.1 \\
\hline \multicolumn{13}{|l|}{ Western Bohemia } \\
\hline 9. Hradišt'ský vrch & 9 & 10.7 & 411 & 0.075 & $0.703464 \pm 11$ & 0.70345 & 29.3 & 6.70 & 0.1382 & $0.512815 \pm 12$ & 0.51281 & 3.7 \\
\hline 29.1. Stráž nad Ohří & 28 & 10.6 & 523 & 0.059 & $0.703673 \pm 11$ & 0.70365 & 27.3 & 5.85 & 0.1295 & $0.512746 \pm 6$ & 0.51272 & 2.5 \\
\hline 29.2. Stráž nad Ohřía & 28 & 8.26 & 505 & 0.047 & $0.703655 \pm 11$ & 0.70364 & 29.9 & 6.28 & 0.1266 & $0.512800 \pm 12$ & 0.51278 & 3.6 \\
\hline 30.1. Vlčí hora, scoria & 12 & 9.00 & 494 & 0.053 & $0.703482 \pm 11$ & 0.70347 & 16.9 & 4.38 & 0.1566 & $0.512748 \pm 8$ & 0.51274 & 2.4 \\
\hline 30.2. Vlčí hora, scoria ${ }^{a}$ & 12 & 9.28 & 461 & 0.058 & $0.703443 \pm 11$ & 0.70343 & 16.39 & 4.32 & 0.1592 & $0.512781 \pm 12$ & 0.51277 & 3.0 \\
\hline 31.1. Vlčí hora, lava & 12 & 8.50 & 512 & 0.048 & $0.703530 \pm 20$ & 0.70352 & 15.9 & 4.19 & 0.1592 & $0.512775 \pm 7$ & 0.51276 & 2.9 \\
\hline 31.2. Vlčí hora, lava ${ }^{a}$ & 12 & 8.89 & 520 & 0.049 & $0.703418 \pm 11$ & 0.70341 & 16.4 & 4.29 & 0.1587 & $0.512820 \pm 11$ & 0.51281 & 3.8 \\
\hline 33. Mýtina & 0.3 & 14.5 & 274 & 0.153 & $0.703284 \pm 13$ & 0.70328 & 10.9 & 2.92 & 0.1619 & $0.512815 \pm 6$ & 0.51281 & 3.6 \\
\hline \multicolumn{13}{|l|}{ Clinopyroxene } \\
\hline 9C. Hradišt'ský vrch ${ }^{\mathrm{a}}$ & 9 & 1.0 & 20.2 & 0.140 & $0.703524 \pm 13$ & 0.70351 & 13.6 & 3.64 & 0.1616 & $0.512806 \pm 22$ & 0.5128 & 3.5 \\
\hline 30.1C. Vlčí hora, scoria ${ }^{a}$ & 12 & 0.6 & 20.6 & 0.084 & $0.703403 \pm 12$ & 0.70339 & 13.2 & 3.65 & 0.1682 & $0.512795 \pm 23$ & 0.51278 & 3.3 \\
\hline 30.2C. Vlčí hora, scoria ${ }^{a}$ & 12 & 0.6 & 16.7 & 0.100 & $0.703487 \pm 11$ & 0.70347 & 7.59 & 2.04 & 0.1626 & $0.512822 \pm 18$ & 0.51281 & 3.8 \\
\hline 31C. Vlčí hora, lava ${ }^{\mathrm{a}}$ & 12 & 1.5 & 22.9 & 0.189 & $0.703374 \pm 11$ & 0.70334 & 8.85 & 2.38 & 0.1623 & $0.512808 \pm 16$ & 0.5128 & 3.5 \\
\hline 36C. Vlčí hora, tuff & 12 & 0.76 & 115 & 0.019 & $0.703550 \pm 9$ & 0.70355 & 14.8 & 3.96 & 0.1617 & $0.512752 \pm 9$ & 0.51274 & 2.4 \\
\hline
\end{tabular}

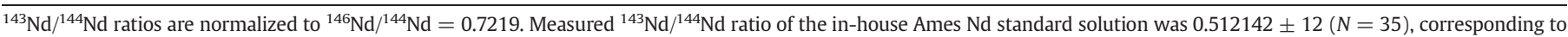

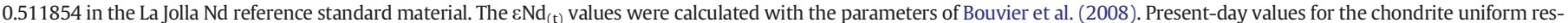

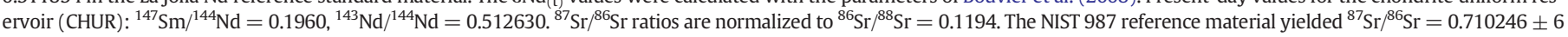
(2SD, $N=22$ ) at the time of sample analysis.

a samples measured in 2008: ${ }^{143} \mathrm{Nd} /{ }^{144} \mathrm{Nd}$ ratios normalized to ${ }^{146} \mathrm{Nd} /{ }^{144} \mathrm{Nd}=0.7219$ (number of ratios in parentheses, error $2 \sigma_{\text {mean }}$ refers to last digit of ratio). Fifteen analyses of JNdi-

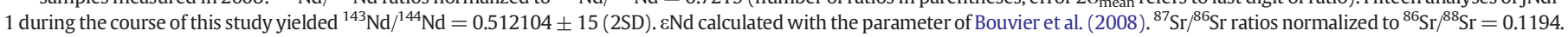
Six measurements of NIST NBS987 gave ${ }^{87} \mathrm{Sr} /{ }^{86} \mathrm{Sr}=0.710211 \pm 7$.

compositional trends of the studied amphiboles from the BM and the Rhön area and those of vein and disseminated amphiboles from mantle peridotites widely overlap in most trace elements. Only Ti concentrations in amphiboles from the BM and the Rhön area are similar to those in vein amphiboles but substantially differ from those in disseminated type of amphiboles, with the latter being only one-third of the former on average (cf. Powell et al., 2004Witt-Eickschen et al., 2003). Moreover, amphiboles of basaltic rocks from the BM and the Rhön area show specific normalized REE patterns, which are similar to those for amphiboles from veins in peridotite xenoliths (Fig. 4b). This is also confirmed by their position in the $\mathrm{Nb} / \mathrm{Th} v s$. Lu/Hf diagram, where amphiboles of the BM as well as those from the Rhön area plot in the field of vein amphiboles (Mayer et al., 2013), see Fig. 9.

\section{2. $p$-T conditions of amphibole crystallization}

The geochemical composition of amphibole is sensitive to pressure and temperature conditions as well as to the host rock composition. Thus, amphibole is very suitable for the estimation of $\mathrm{p}-\mathrm{T}$ conditions under which it crystallized from the host magma (Mutch et al., 2016). Several amphibole-based thermobarometers have been proposed for different igneous systems (e.g., Putirka, 2016; Ridolfi and Renzulli, 2012). Regarding the geochemistry of the basaltic host rocks the amphibole thermometer of Ridolfi and Renzulli (2012) was chosen as the most relevant for the calculation of temperatures of crystallization. On the other hand, the Ridolfi and Renzulli (2012) barometer may be too sensitive for subtle compositional variations in amphibole and may introduce large uncertainty in the estimation of the depth of magma emplacement. We used an empirical barometrer of Pál-Molnár et al. (2015) based on the $\mathrm{Al}_{2} \mathrm{O}_{3}$ contents in amphibole, which was calibrated using data of experimentally produced amphiboles. Temperature and pressure ranges calculated for most amphibole samples of all rock associations of types A-E are $1024-1100{ }^{\circ} \mathrm{C} \pm 23.5^{\circ} \mathrm{C}$ and $0.7-1.2 \mathrm{GPa}$ (i.e., $\sim 20-45 \mathrm{~km}$ ), see Fig. 10. These p-T calculations are compatible with the experimental data on the stability of kaersutite supposedly derived from the upper mantle (Green et al., 2010; Pilet et al., 2010 and references therein). Generally, amphibole samples of the rock association of type B (phenocrysts/xenocrysts in lamprophyres) yielded slightly higher temperatures. Amphibole samples of the rock association of type D (partly disintegrated xenoliths of hornblendite cumulates in sodalite syenites) can be divided into a group forming cores of amphiboles, yielding $1050-1070{ }^{\circ} \mathrm{C}$ and $0.7-1.0 \mathrm{GPa}(\sim 20-35 \mathrm{~km})$, and a 


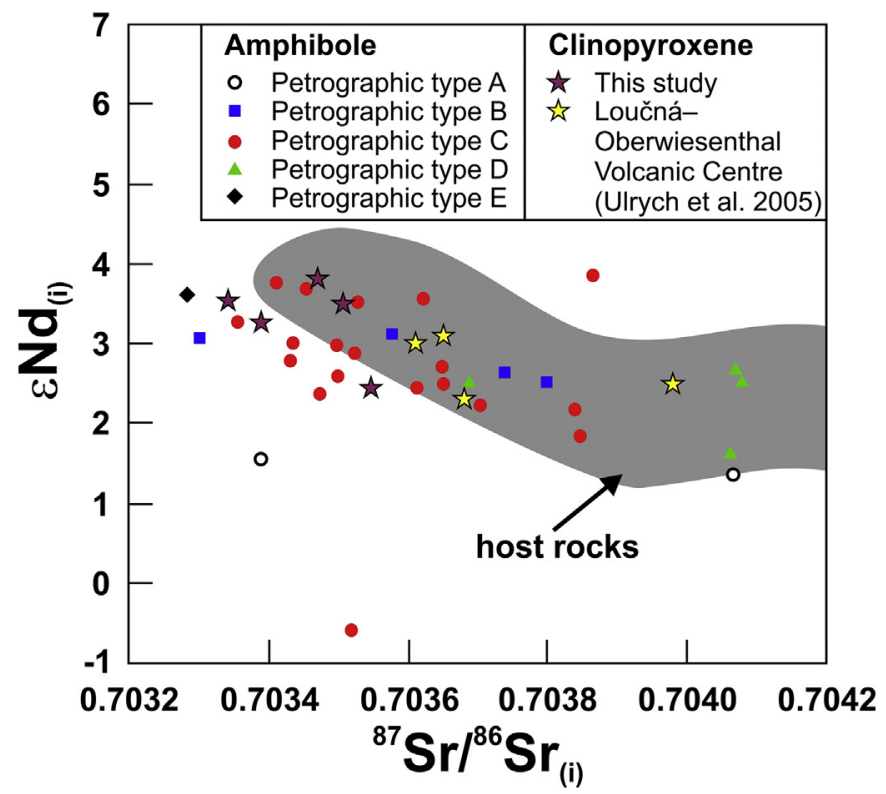

Fig. 7. Initial ${ }^{87} \mathrm{Sr} /{ }^{86} \mathrm{Sr} v s$. \&Nd isotopic values of amphiboles and clinopyroxenes from Cenozoic volcanic rocks of the Bohemian Massif. The grey area marks isotopic composition of their host rocks listed in Supplement S5. Data for clinopyroxene from amphibole-bearing xenoliths from the Loučná-Oberwiesenthal Volcanic Centre were taken from Ulrych et al. (2005).

group forming outer rims of amphibole crystals, characterized by temperatures between 980 and $1000{ }^{\circ} \mathrm{C}$ and lower pressures between 0.47 and $0.57 \mathrm{GPa}(\sim 15 \mathrm{~km})$ originating en route of magma ascent. Hornblendites should represent either side-wall contamination of the host salic magma, or a disrupted and ascended product of mafic melt observed in the late stage of lamprophyre dykes genesis (cf. Ditrău Alkaline Massif - Batki et al., 2014). An amphibole xenocryst of the rock association of type E showed p-T conditions of $1030-1040{ }^{\circ} \mathrm{C}$ and $0.95-$

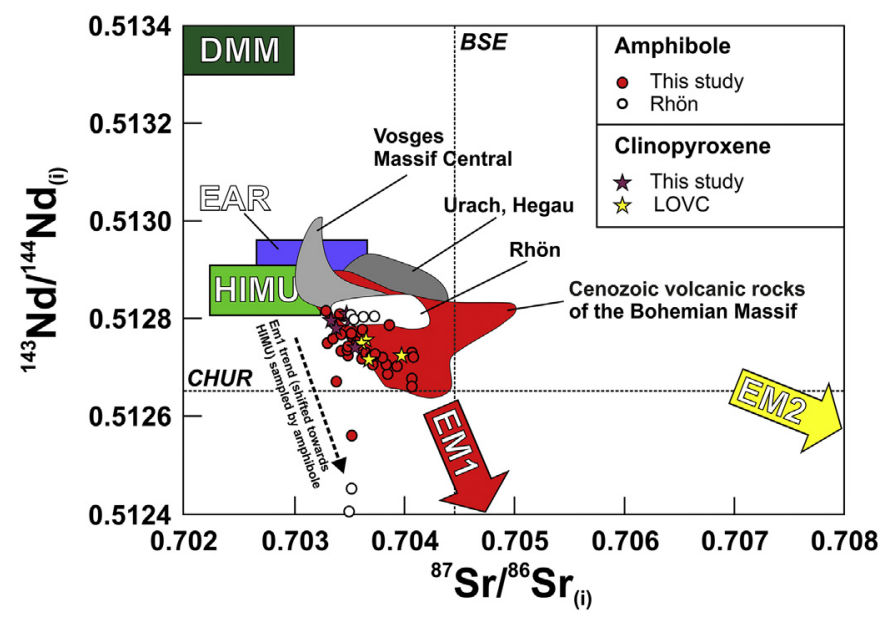

Fig. 8. Initial ${ }^{87} \mathrm{Sr} /{ }^{86} \mathrm{Sr} v s .{ }^{143} \mathrm{Nd} /{ }^{144} \mathrm{Nd}$ isotope ratios for amphibole and clinopyroxene from Cenozoic volcanic rocks of the Bohemian Massif. Amphibole samples show a trend towards EM1-type mantle which can be partly shifted towards HIMU. Plotted for comparison are the fields for the Cenozoic volcanics of the Bohemian Massif (Haase and Renno, 2008; Lustrino and Wilson, 2007; Ulrych et al., 2008, 2013, 2016, 2017); for Urach and Hegau (Alibert et al., 1983; Hegner et al., 1995; Wilson et al., 1995); for the Rhön area (Mayer et al., 2013 - amphibole-bearing lavas; Mayer et al., 2014 - amphibole samples); for the Loučná-Oberwiesenthal Volcanic Centre (LOVC; Ulrych et al., 2005 - clinopyroxene samples) and for the Massif Central/Vosges (Alibert et al., 1983) are plotted for comparison. $\mathrm{BSE}=$ Bulk Silicate Earth; CHUR $=$ Chondritic Uniform Reservoir; DMM $=$ Depleted MORB Mantle; EAR = European Asthenospheric Reservoir; HIMU = high $\mu$ $\left({ }^{238} \mathrm{U} /{ }^{204} \mathrm{~Pb}\right)$; EM1 = Enriched Mantle 1; EM2 = Enriched Mantle 2 (Cebrià and Wilson, 1995; Granet et al., 1995; Hart, 1988; Zindler and Hart, 1986).

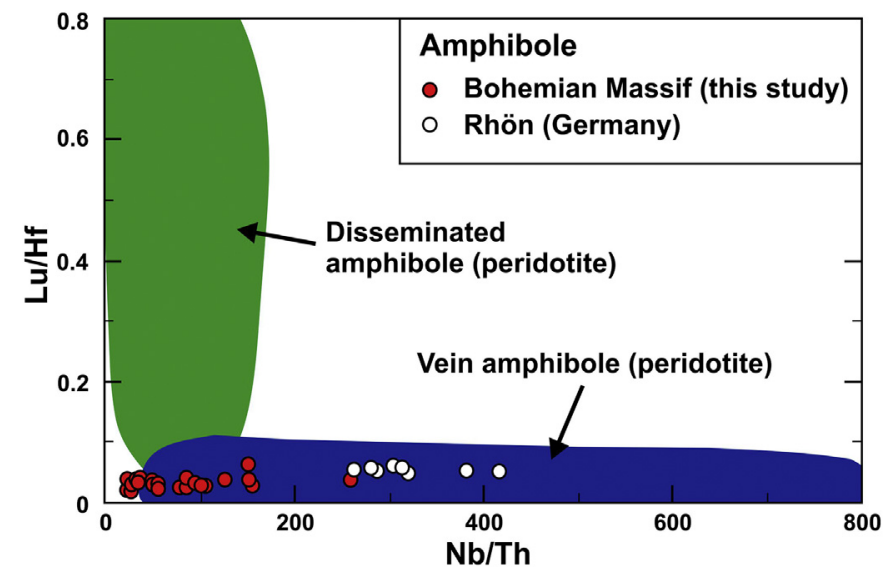

Fig. 9. $\mathrm{Nb} / \mathrm{Th}$ vs. Lu/Hf diagram for the studied amphiboles, and published representative vein amphibole and disseminated amphibole compositions from peridotites (Ionov and Hofmann, 1995; Powell et al., 2004; Witt-Eickschen et al., 2003).

1.0 GPa ( $\sim 35 \mathrm{~km})$. This amphibole crystallized under a relatively lower pressure than should be expected for mantle xenoliths (cf. Ducea and Saleeby, 1996); however, the Moho discontinuity in western Bohemia with the youngest Plio-Pleistocene volcanoes of the BM was detected at a depth starting approximately at $27 \mathrm{~km}$ because of thinned lithosphere beneath the OR (Hrubcová and Geissler, 2009 and references therein).

Genesis of the megacrysts and xenoliths of amphiboles took place in a deep magma chamber situated close to the crust-mantle boundary (cf. Bondi et al., 2002). Crystallization temperatures of our samples are consistent with the hornblende p-T estimations of Mayer et al. (2014) calculated using the thermobarometer of Ridolfi and Renzulli (2012). All amphiboles fall into the stability field of kaersutite in mafic lavas (Green et al., 2010).

\subsection{Sr-Nd isotope signature of amphiboles}

The similar ${ }^{143} \mathrm{Nd} /{ }^{144} \mathrm{Nd}$ and ${ }^{87} \mathrm{Sr} /{ }^{86} \mathrm{Sr}$ ratios of amphiboles and the host alkaline basaltic rocks (Fig. 8) is commonly explained by similar fluid phase activities. The isotopic composition of amphibole is controlled by such a fluid phase of asthenospheric affinity and parallels that of the host basaltic rocks (Othman et al., 1990). Both amphibole and clinopyroxene xenocrysts in host basaltic rocks from western Bohemia show the same isotopic sources. However, Miller (1982) and Han et al. (2008) suggested a non-cognate relationship between amphibole/ clinopyroxene megacrysts and host basalts.

Metasomatized composite peridotite xenoliths with clinopyroxene/ amphibole veins similar to those reported from numerous volcanoes elsewhere (e.g., Western Victoria, Australia - Powell et al., 2004; Meerfelder maar, Germany - Witt-Eickschen et al., 1998) have not been found in the BM yet. Rare disseminated amphibole and phlogopite crystals in mantle peridotite/pyroxenite xenoliths have been reported from the Elbe Zone, Saxony (Kramer and Seifert, 2000), the Wilcza Góra in Poland (Matusiak-Malek et al., 2017) and a cinder cone in the Cheb-Domažlice Graben, western Bohemia (Geissler et al., 2007).

Trace element contents and initial Sr-Nd isotopic ratios of amphiboles of the broad kaersutite series and their host rocks do not demonstrate substantial regional variations in the lithospheric mantle composition beneath the BM. The Sr-Nd isotopic ratios of kaersutites from pyroxenite cumulate from the Loučná-Obwerwiesenthal Volcanic Centre (Ulrych et al., 2005) plot also into the field of the studied amphiboles. The only exception is the amphibole megacryst from Lukov, sample $1.1\left(\varepsilon \mathrm{Nd}_{(\mathrm{i})}=-0.6\right)$ from the central part of the CSVC, probably showing a notable influence of recycled Variscan crustal material in the upper mantle (Lustrino and Wilson, 2007) during the melting. Similar negative $\varepsilon \mathrm{Nd}_{(\mathrm{i})}$ values ( -4.0 to -2.9$)$ for kaersutite from the Rhön 


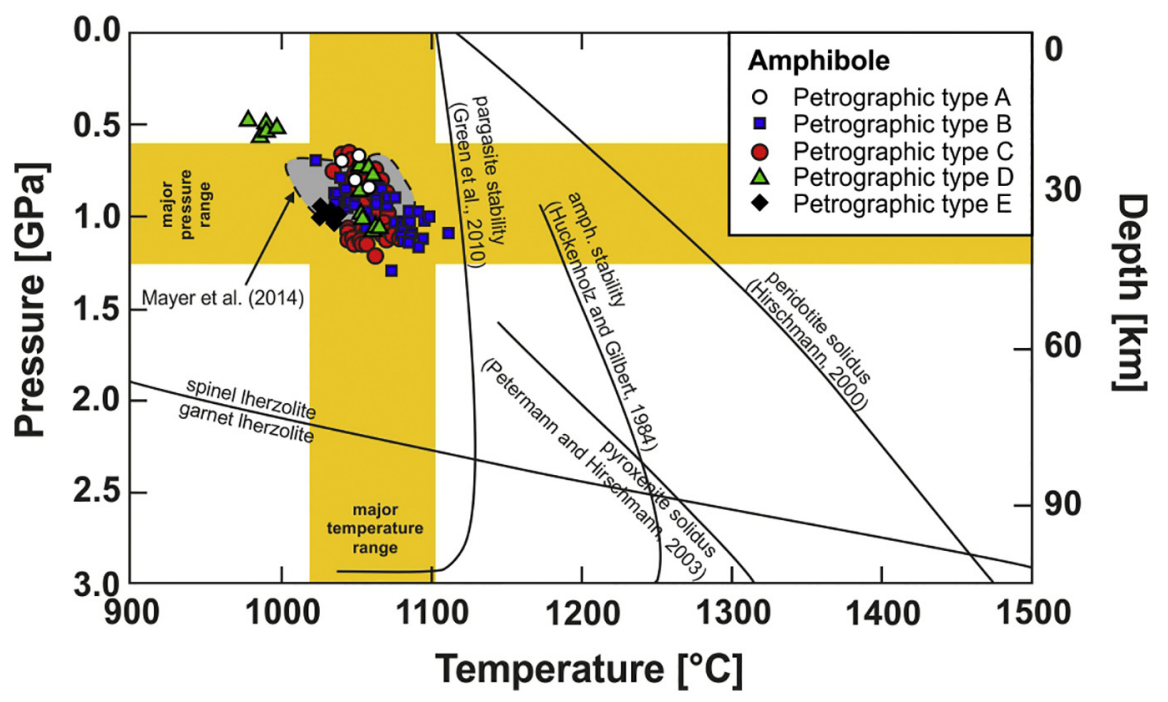

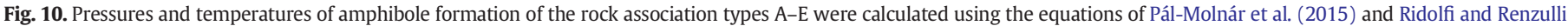

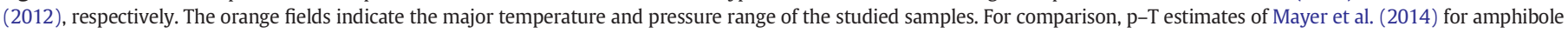
are also shown. The spinel/garnet lherzolite stability fields follow Falloon and Green (1990), Foley (1991) and Robinson and Wood (1998).

area (Mayer et al., 2014) are explained by the involvement of an ancient crustal-derived metasomatic component within the mantle source during the Variscan orogeny. Liew and Hofmann (1988) presented the following isotope data for the Variscan basement from the BM: ${ }^{143} \mathrm{Nd} /{ }^{144} \mathrm{Nd}_{(\mathrm{m})}$ of 0.5109 to 0.5119 , $\varepsilon \mathrm{Nd}$ of -24.5 to -5.7 and ${ }^{87} \mathrm{Sr} /{ }^{86} \mathrm{Sr}$ as high as 0.72 . The origin of geochemical domains, and particularly Nd-Sr isotope variations in volcanic domains, arise from local heterogeneities in metasomatically veined hydrous mantle (Menzies and Murthy, 1980). A fertile domain in the mantle could have arisen from the material of a Variscan buoyant slab not subducted into the deeper mantle. After a thermal equilibration with the mantle this slab caused the heterogeneity of the lithospheric mantle. Geophysical and geochemical evidence for a continuous evolution of the post-Variscan mantle lithosphere in central Europe throughout the Mesozoic and Cenozoic was presented by Meier et al. (2016). The mantle lithosphere in western and central Europe evolved and was continuously modified during an extensional Variscan and post-Variscan cycle.

\section{Conclusions}

The studied amphibole phenocrysts/xenocrysts and cumulate xenoliths from Cenozoic volcanic rocks of the BM belong to the magnesiohastingsite-pargasite-kaersutite series and their genesis is mostly directly associated with that of alkaline basaltic magmas. Amphibole xenocrysts from disaggregated cumulate xenoliths of hornblendite cumulate xenoliths occur in differentiated trachytic rocks. Chemical and $\mathrm{Sr}-\mathrm{Nd}$ isotopic characteristics of all studied amphiboles resemble those of amphiboles from clinopyroxene/amphibole veins in peridotites, rather than those of disseminated amphiboles in mantle peridotites.

Amphibole phenocrysts/xenocrysts of the Cenozoic volcanic rocks of the BM are mostly chemically homogeneous, lacking prominent zoning. Only amphiboles of the xenolith of hornblendite cumulate from "Giegelberg" show a substantial Mg-Fe fractionation.

The studied amphiboles are characterized by variable incompatible element concentrations. Their lowest concentrations were found in amphiboles of xenocrysts and megacrysts in alkaline basaltic rocks and mantle xenoliths, followed by phenocrysts/xenocrysts in lamprophyric rocks, xenocrysts in felsic rocks, and phenocrysts in subvolcanic rocks.

The presence of residual amphibole in the source(s) of magma is characteristic for most Cenozoic primary volcanic rocks in the BM (Ulrych et al., 2011) and requires melting conditions typical for the asthenosphere-lithosphere boundary, near the supposed position of the EAR.

The calculated p-T conditions do not contradict this model; almost all amphiboles crystallized in a relatively narrow temperature range of $1020-1100{ }^{\circ} \mathrm{C}$ at depths corresponding to $\sim 20-45 \mathrm{~km}(0.7-1.2 \mathrm{GPa})$. We therefore suggest that amphibole (phenocrysts) crystallized at different depths of the lithospheric mantle near the crust-mantle transition during the magma ascent (Hrubcová and Geissler, 2009). Xenocrysts and xenoliths-autoliths are products of side-wall contamination en route of the basaltic magma ascent and/or in a deep magma chamber (sensu Bondi et al., 2002). Anomalous rims of amphibole in xenoliths of cumulates from "Giegelberg" yielded calculated temperatures between 980 and $1000{ }^{\circ} \mathrm{C}$ and pressures between 0.48 and $0.57 \mathrm{GPa}$ $(\sim 15 \mathrm{~km})$. These $\mathrm{p}-\mathrm{T}$ estimates are compatible with the published experimental data on the stability of kaersutite.

Initial ${ }^{143} \mathrm{Nd} /{ }^{144} \mathrm{Nd}(0.51266-0.51281)$ and ${ }^{87} \mathrm{Sr} /{ }^{86} \mathrm{Sr}$ values (0.70328-0.70407) of amphiboles are significantly similar to those of their host rocks $\left({ }^{143} \mathrm{Nd} /{ }^{144} \mathrm{Nd}_{(\mathrm{i})}=0.51266-0.51288\right.$ and ${ }^{87} \mathrm{Sr} /{ }^{86} \mathrm{Sr}_{(\mathrm{i})}=$ 0.70341-0.70462). Amphiboles and their host rocks plot into the field for Cenozoic volcanic rocks of the BM and CEVP, near the position of the EAR. The studied amphibole set is characterized by homogeneous positive $\varepsilon \mathrm{Nd}_{(\mathrm{i})}$ values ( +1.4 to +3.8 ), only a sole sample (sample $1-$ Lukov) has a negative $\varepsilon \mathrm{Nd}_{(\mathrm{i})}(-0.6)$. This testifies to the presence of a locally prominent mantle domain enriched in recycled Variscan crustal material during the melting.

The genesis of amphiboles of the kaersutite series in basaltic rocks in the BM is associated with a metasomatically veined mantle peridotites, generated by metasomatic fluids enriched in HFSE from the EM1-type mantle.

\section{Acknowledgements}

This research was financially supported by the institutional project RVO 67985831 of the Institute of Geology of the Czech Academy of Sciences, as well as by the BUT project L01408 "AdMaS UP - Advanced Materials, Structures and Technologies", supported by the Ministry of Education, Youth and Sports CR under the "National Sustainability Programme I". The isotope studies were conducted only through the generosity of Ernst Hegner from Ludwig-Maximilians-Universität München. He is also thanked for his comments to the early version of the manuscript. The last version of manuscript was consulted with Jarda Dostal, Saint Mary's University, Halifax, Nova Scotia, who also improved the 
English of the manuscript. Constructive comments were provided by Anikó Batki and an anonymous reviewer, and the editor Andrew Kerr helped us to refine significantly the original manuscript.

\section{Appendix A. Supplementary data}

Supplementary data to this paper are (i) Mineralogical and petrologic characteristics of amphibole localities in Cenozoic volcanic rocks of the Bohemian Massif (S1A), (ii) Field relationships and observations of the sampled amphibole localities (S1B), (iii) Representative chemical analyses of amphibole from volcanic rocks of the Bohemian Massif (S2), (iv) Additional trace element contents of amphiboles from volcanic rocks of the Bohemian Massif (S3), (v) Chemical and trace element analyses of clinopyroxene from volcanic rocks of Western Bohemia (S4), and (vi) Chemical analyses and $\mathrm{Sr}-\mathrm{Nd}$ isotope data of the kaersutite host Cenozoic volcanic rocks of the Bohemian Massif (S5). Supplementary data to this article can be found online at doi: https://doi.org/10.1016/j.lithos. 2018.05.017.

\section{References}

Ackerman, L., Medaris Jr., L.G., 2017. The composition of upper mantle beneath the Bohemian Massif: the view from mantle xenoliths. Abstracts and Excursion Guides Basalt 2017 Kadaň, Czech Geological Society and Czech Geological Survey, p. 7.

Ackerman, L., Medaris, G., Špaček, P., Ulrych, J., 2015a. Geochemical and petrological constraints on mantle composition of the Ohře (Eger) Rift, Bohemian Massif: peridotite xenoliths from the České Stř̌edohoří volcanic complex and northern Bohemia. International Journal of Earth Sciences 104, 1957-1979.

Ackerman, L., Ulrych, J., Řanda, Z., Erban, V., Hegner, Magna, T., Balogh, K., Frána, J., Lang M., Novák, J.K., 2015b. Geochemical characteristics and petrogenesis of phonolites and trachytic rocks from the České Středohoří volcanic complex, the Ohře Rift, Bohemian Massif. Lithos 224-225, 256-271.

Alibert, C., Michard, A., Albarède, F., 1983. The transition from alkali basalts to kimberlites: isotope and trace element evidence from melilitites. Contributions to Mineralogy and Petrology 82, 176-186

Batki, A., Pál-Molnár, E., Dobosi, G., Skelton, A., 2014. Petrogenetic significance of ocellar camptonite dykes in the Ditrău Alkaline Massif. Lithos 200-201, 181-196.

Bondi, M., Morten, L., Nimis, P., Rossi, P.L., Tranne, C.A., 2002. Megacrysts and mafic-ultramafic xenolith-bearing ignimbrites from Sirwa volcano, Morocco: phase petrology and thermobarometry. Mineralogy and Petrology 75, 203-221.

Bourgeois, O., Ford, M., Diraison, M., Le Carlier de Veslud, C., Gerbault, M., Pik, R., Ruby, N., Bonnet, S., 2007. Separation of rifting and lithospheric folding signatures in the NWalpine foreland. International Journal of Earth Sciences 96, 1003-1031.

Boynton, W.V., 1984. Cosmochemistry of the rare earth elements: meteorite studies. In: Henderson, P. (Ed.), Rare Earth Element Geochemistry. Elsevier, Amsterdam, pp. 63-114.

Bouvier, A., Vervoort, J.D., Patchett, P.J., 2008. The Lu-Hf and Sm-Nd isotopic composition of CHUR: Constraints from unequilibrated chondrites and implications for the bulk composition of terrestrial planets. Earth and Planetary Science Letters 273, 48-57.

Cebrià, J.M., Wilson, M., 1995. Cenozoic mafic magmatism in Western/Central Europe. A common European asthenospheric reservoir. Terra Nova 162 abstract supplement 7.

Class, C., Goldstein, S.L., 1997. Plume-lithosphere interaction in the ocean basins: constraints from source mineralogy. Earth and Planetary Science Letters 150, 245-260.

Coubal, M., Málek, J., Adamovič, J., Štěpančíková, P., 2015. Late Cretaceous and Cenozoic dynamics of the Bohemian Massif inferred from the paleostress history of the Lusatian Fault Belt. Journal of Geodynamics 87, 26-49.

Dawson, J.B., Smith, J.V., 1982. Upper-mantle amphiboles: a review. Mineralogical Magazine $45,35-46$

De Angelis, S.H., Larsen, J., Coombs, M., Dunn, A., Hayden, L., 2015. Amphibole reaction rims as a record of pre-eruptive magmatic heating: an experimental approach. Earth and Planetary Science Letters 426, 235-245.

Dèzes, P., Schmid, S.M., Ziegler, P.A., 2004. Evolution of the European Cenozoic Rift System: interaction of the Alpine and Pyrenean orogens with their foreland lithosphere. Tectonophysics 389, 1-33.

Dobosi, G., Downes, H., Embey-Isztin, A., Jenner, G.A., 2003. Origin of megacrysts and pyroxenite xenoliths from the Pliocene alkali basalts of the Pannonian Basin (Hungary). Neues Jahrbuch für Mineralogie (Abhandlungen) 173, 217-237.

Dostal, J., Shellnutt, J.G., Ulrych, J., 2017. Petrogenesis of the Cenozoic alkaline volcanic rock series of the České Stř̌edohoří Complex (Bohemian Massif), Czech Republic: a case for two lineages. American Journal of Science 317, 677-706.

Ducea, M.N., Saleeby, J.B., 1996. Buoyancy sources for a large, unrooted mountain range, the Sierra Nevada, California: Evidence from xenolith thermobarometry. Journal of Geophysical Research: Solid Earth 101, 8229-8244.

Ellis, D.J., 1976. High-pressure cognate inclusions in the Newer Volcanics of Victoria. Contributions to Mineralogy and Petrology 58, 149-180.

Falloon, T.J., Green, D.H., 1990. Solidus of carbonated fertile peridotite under fluid-saturated conditions. Geology 18, 195-199.

Foley, S., 1991. High-pressure stability of the fluor- and hydroxy-endmembers of pargasite and K-richterite. Geochimica et Cosmochimica Acta 55, 2689-2694.
Francalanci, L., Avanzinelli, R., Nardini, I., Tiepolo, M., Davidson, J.P., Vannucci, R., 2012 Crystal recycling in the steady-state system of the active Stromboli volcano: a 2.5ka story inferred from in situ Sr-isotope and trace element data. Contributions to Mineralogy and Petrology 163, 109-131.

Frey, F.A., Green, D.H., Roy, S.D., 1978. Integrated models of basalt petrogenesis: a study of quartz tholeiites to olivine melilitites from southeastern Australia utilizing geochemical and experimental petrological data. Journal of Petrology 19, 463-513.

Frost, S.J., 2006. The stability of hydrous mantle phases. Reviews in Mineralogy and Geochemistry 62, 243-271.

Geissler, W.F., Kämpf, H., Seifert, W., Dulski, P., 2007. Petrological and seismic studies of the lithosphere in the earthquake swarm region Vogtland/NW Bohemia, Central Europe. Journal of Volcanology and Geothermal Research 159, 33-69.

Granet, M., Wilson, M., Achauer, U., 1995. Imaging a mantle plume beneath the French Massif Central. Earth and Planetary Science Letters 136, 199-203.

Green, D.H., Hibberson, W.O., Kovacs, I., Rosenthal, A., 2010. Water and its influence on the lithosphere-asthenosphere boundary. Nature 467, 448-451.

Haase, K.M., Renno, A.D., 2008. Variation of magma generation and mantle sources during continental rifting observed in Cenozoic lavas from the Eger Rift, Central Europe. Chemical Geology 257, 195-205.

Han, B., Liu, J., Zhang, L., 2008. A noncognate relationship between megacrysts and host basalts from the Tuoyun Basin, Chinese Tian Shan. Journal of Geology 116, 499-509.

Hart, S.R., 1988. Heterogeneous mantle domains: signatures, genesis and mixing chronologies. Earth and Planetary Science Letters 90, 273-296.

Hawthorne, F.C., Oberti, R., Harlow, G.E., Maresch, W.V., Martin, R.F., Schumacher, J.C., Welch, M.D., 2012. Nomenclature of the amphibole supergroup. American Mineralogist 97, 2031-2049.

Hegner, E., Walter, H.J., Satir, M., 1995. Pb-Sr-Nd isotopic compositions and trace element geochemistry of megacrysts and melilitites from the Tertiary Urach volcanic field: source composition of small volume melts under SW Germany. Contribution to Mineralogy and Petrology 122, 322-335.

Hoernle, K., Zhang, Y., Graham, D., 1995. Seismic and geochemical evidence for large-scale mantle upwelling beneath the Eastern Atlantic and Western and Central Europe. Nature 374, 34-39.

Hrubcová, P., Geissler, W.H., 2009. The crust-mantle transition and the Moho beneath the Vogtland/West Bohemian region in the light of different seismic methods. Studia Geophysica et Geodaetica 53, 275-294.

Ionov, D.A., Hofmann, A.W., 1995. Nb-Ta mantle amphiboles and micas: Implications for subduction-related metasomatic trace element fractionations. Earth and Planetary Science Letters 131, 341-356.

Jochum, K.P., Nohl, U., 2008. Reference materials in geochemistry and environmental research and the GeoReM database. Chemical Geology 253, 50-53.

Kramer, W., Seifert, W., 2000. Mafische Xenolithe und Magmatite im östlichen Saxothuringikum und westlichen Lugikum: Ein Beitrag zum Krustenbau und zur regional Geologie. Zeitschrift für Geologische Wissenschaften 28, 133-156.

Krmíček, L., Romer, R.L., Ulrych, J., Glodny, J., Prelević, D., 2016. Petrogenesis of orogenic lamproites of the Bohemian Massif: Sr-Nd-Pb-Li isotope constraints for Variscan enrichment of ultra-depleted mantle domains. Gondwana Research 35, 198-216.

Le Maitre, R.W. (Ed.), 2002. Igneous Rocks. A Classification and Glossary of Terms, second ed. Cambridge University Press, Cambridge.

Leake, B.E., et al., 1997. Nomenclature of amphiboles: Report of the subcommittee on amphiboles of the international association, commission on new minerals and mineral names. American Mineralogist 82, 1019-1037.

Liew, T.C., Hofmann, A.W., 1988. Precambrian crustal components, plutonic associations, plate environment of the Hercynian Fold Belt of central Europe: Indications from a Nd and $\mathrm{Sr}$ isotopic study. Contributions to Mineralogy and Petrology 98, $129-138$.

Locock, A.J., 2014. An Excel spreadsheet to classify chemical analyses of amphiboles following the IMA 2012 recommendations. Computers \& Geosciences 62, 1-11.

Lustrino, M., Wilson, M., 2007. The circum-Mediterranean anorogenic Cenozoic igneous province. Earth-Science Review 81, 1-65.

Martin, R.F., 2007. Amphiboles in the igneous environment. Reviews in Mineralogy \& Geochemistry. 67. America, Mineralogical Society of, pp. 323-358.

Matusiak-Malek, M., Puziewicz, J., Ntaflos, T., Grégoire, M., Kukula, A., Wojtulek, P.M., 2017. Origin and evolution of rare amphibole-bearing mantle peridotites from Wilcza Góra (SW Poland), Central Europe. Lithos 286-287, 302-323.

Mayer, B., Jung, S., Romer, R.L., Pfänder, J.A., Klügel, A., Pack, A., Gröner, E., 2014. Amphibole in alkaline basalts from intraplate settings: implications for the petrogenesis of alkaline lavas from the metasomatised lithospheric mantle. Contribution to Mineralogy and Petrology 167, 988-989.

Mayer, B., Jung, S., Romer, R.L., Stracke, A., Haase, K.M., Garbe-Schönberg, C.-D., 2013. Petrogenesis of Tertiary hornblende-bearing lavas in the Rhön, Germany. Journal of Petrology 54, 2095-2123.

McDonough, W.F., Sun, S., 1995. The composition of the Earth. Chemical Geology 120, 223-253.

Meier, T., Soomro, R.A., Viereck, L., Lebedev, S., Behrmann, J.H., Weidle, C., Cristiano, L., Hanemann, R., 2016. Mesozoic and Cenozoic evolution of the Central European lithosphere. Tectonophysics 692, 58-73.

Menzies, M.A., Murthy, V.R., 1980. Nd and Sr isotope geochemistry of hydrous mantle nodules and their implication for local heterogeneities in metasomatically veined mantle. Earth and Planetary Science Letters 46, 323-334.

Miller, C., 1982. Geochemical constraints on the origin of xenolith-bearing alkali basaltic rocks and megacrysts from the Hoggar, central Sahara. Geochemical Journal 16 225-236.

Morimoto, N., Fabries, J., Ferguson, A.K., Ginzburg, I.V., Ross, M., Seifert, F.A., Zussman, L., Aoki, K., Gottardi, G., 1988. Nomenclature of pyroxenes. Mineralogy and Petrology 39, 201-211. 
Mutch, E.J.F, Blundy, J.D., Tattitch, B.C., Cooper, F.J., Brooker, R.A., 2016. An experimenta study of amphibole stability in low-pressure graniticmagmas and a revised $\mathrm{Al}$-inhornblende geobarometer. Contributions to Mineralogyand Petrology 171, 85.

Othman, D.B., Tilton, G.R., Menzies, M.A., 1990. Pb, Nd, and Sr isotopic investigations of kaersutite and clinopyroxene from ultramafic nodules and their host basalts: The nature of the subcontinental mantle. Geochimica et Cosmochimica Acta 54 3449-3460.

Pál-Molnár, E., Batki, A., Almasi, E., Kiss, B., Upton, B.G.J., Markl, G., Odling, N., Harangi, S. 2015. Origin of mafic and ultramafic cumulates from the Ditrău Massif, Romania. Lithos 239, 1-18.

Pilet, S., Ulmer, P., Villiger, S., 2010. Liquid line of descent of a basanitic liquid at $1.5 \mathrm{GPa}$ constraints on the formation of metasomatic veins. Contribution to Mineralogy and Petrology 159, 621-643.

Powell, W., Zhang, M., O'Reilly, S.Y., Tiepolo, M., 2004. Mantle amphibole trace-element and isotopic signatures trace multiple metasomatic episodes in lithospheric mantle, western Victoria, Australia. Lithos 75, 141-171.

Putirka, K., 2016. Amphibole thermometers and barometers for igneous systems and some implications for eruption mechanisms of felsic magmas at arc volcanoes. American Mineralogist 101, 841-858.

Ridolfi, F., Renzulli, A., 2012. Calcic amphiboles in calc-alkaline and alkaline magmas: thermobarometric and chemometric empirical equations valid up to $1,130{ }^{\circ} \mathrm{C}$ and 2.2 GPa. Contributions to Mineralogy and Petrology 163, 877-895.

Righter, K., Carmichael, I.S.E., 1993. Mega-xenocrysts in alkali olivine basalts: fragments of disrupted mantle assemblages. American Mineralogist 78, 1230-1245.

Robinson, J.A.C., Wood, B.J., 1998. The depth of the spinel to garnet transition at the peridotite solidus. Earth and Planetary Science Letters 164, 277-284.

Shaw, C.S.J., Eyzaguirre, J., 2000. Origin of megacrysts in the mafic alkaline lavas of the West Eifel volcanic field, Germany. Lithos 50, 75-95.

Skála, R., Ulrych, J., Ackerman, L., Jelínek, E., Dostal, J., Hegner, E., Řanda, Z., 2014. Tertiary alkaline Roztoky Intrusive Complex, České středohoří Mts., Czech Republic: petrogenetic characteristics. International Journal of Earth Sciences 103, 1233-1262.

Streck, M.J., 2008. Mineral textures and zoning as evidence for open system processes. Reviews in Mineralogy and Geochemistry. 69. Mineralogical Society of America, pp. 595-622.

Ubide, T., Galé, C., Arranz, E., Lago, M., Larrea, P., 2014. Clinopyroxene and amphibole crystal populations in a lamprophyre sill from the Catalonian coastal ranges (NE Spain): A record of magma history and a window to mineral-melt partitioning. Lithos 184-187, 225-242.

Ulrych, J., Ackerman, L., Balogh, K., Hegner, E., Jelínek, E., Pécskay, Z., Přichystal, A., Upton, B.G.J., Zimák, J., Foltýnová, R., 2013. Plio-Pleistocene basanitic and melilititic series of the Bohemian Massif: K-Ar ages, major/trace element and $\mathrm{Sr}-\mathrm{Nd}$ isotopic data. Chemie Erde-Geochemistry 73, 429-450.
Ulrych, J., Adamovič, J., Krmíček, L., Ackerman, L, Balogh, K., 2014. Revision of Scheumann's classification of melilitic lamprophyres and related melilitic rocks in light of new analytical data. Journal of Geosciences 59, 47-66.

Ulrych, J., Dostal, J., Adamovič, J., Jelínek, E., Špaček, P., Hegner, E., Balogh, K., 2011. Recurrent Cenozoic volcanic activity in the Bohemian Massif (Czech Republic). Lithos 123, 133-144.

Ulrych, J., Dostal, J., Hegner, E., Balogh, K., Ackerman, L., 2008. Late Cretaceous to Paleocene melilitic rocks of the Ohře/Eger Rift in northern Bohemia, Czech Republic: insights into the initial stages of continental rifting. Lithos 101, 141-161.

Ulrych, J., Krmíček, L., Teschner, C., Řanda, Z., Skála, R., Jonášová, Š., Fediuk, F., Adamovič, J., Pokorný, R., 2017. Tachylyte in Cenozoic basaltic lavas from the Czech Republic and Iceland: contrasting compositional trends. Mineralogy and Petrology 111, 761-775.

Ulrych, J., Krmíček, L., Tomek, Č., Lloyd, F.E., Ladenberger, A., Ackerman, L., Balogh, K., 2016. Petrogenesis of Miocene alkaline volcanic suites from western Bohemia: whole rock geochemistry and $\mathrm{Sr}-\mathrm{Nd}-\mathrm{Pb}$ isotopic signatures. Chemie der Erde-Geochemistry 76, 77-93.

Ulrych, J., Lloyd, F.E., Balogh, K., Hegner, E., Langrová, A., Lang, M., Novák, J.K., Řanda, Z., 2005. Petrogenesis of alkali pyroxenite and ijolite xenoliths from the Tertiary Loučná-Oberwiesenthal Volcanic Centre, Bohemian Massif in the light of new mineralogical, geochemical and isotopic data. Neues Jahrbuch für Mineralogie (Abhandlungen) 182, 57-79.

Ulrych, J., Svobodová, J., Balogh, K., 2002. The source of Cenozoic volcanism in the České středohoří Mts., Bohemian Massif. Neues Jahrbuch für Mineralogie (Abhandlungen) $177,133-162$.

Wilshire, H.G., 1987. A model of mantle metasomatism. In: Morris, E.M., Pasteris, J.D. (Eds.), Mantle Metasomatism and Alkaline Magmatism. Geological Society of America, p. 215 (Boulder).

Wilson, M., Downes, H., Cebrià, J.M., 1995. Contrasting fractionation trends in coexisting continental alkaline magma series, Cantal, Massif Central, France. Journal of Petrology 36, 1729-1750.

Witt-Eickschen, G., Kaminsky, W., Kramm, U., Harte, B., 1998. The nature of young vein metasomatism in the lithosphere of the West Eifel (Germany): geochemical and isotopic constraints from composite mantle xenoliths from the Meerfelder maar. Journal of Petrology 39, 155-185.

Witt-Eickschen, G., Seck, H.A., Mezger, K., Eggins, S.M., Altherr, R., 2003. Lithospheric mantle evolution beneath the Eifel (Germany): Constraints from $\mathrm{Sr}-\mathrm{Nd}-\mathrm{Pb}$ isotopes and trace element abundances in spinel peridotite and pyroxenite xenoliths. Journal of Petrology 44, 1077-1095.

Ziegler, P.A., 1994. Cenozoic rift system of Western and Central Europe: an overview. Geologie en Mijnbow 73, 99-127.

Zindler, A., Hart, S.R., 1986. Chemical geodynamics. Annual Review of Earth and Planetary Sciences 14, 493-571. 